\title{
Characteristics of long-term variability of precipitation in selected river catchment areas in India based on GPCC data for the years 1901-2010
}

\author{
Bernard Twaróg ${ }^{1}$ \\ Institute of Hydraulic Engineering and Water Management, Department of Hydraulic Engineering and Water \\ Management \\ Faculty of Environmental Engineering, Cracow University of Technology
}

\begin{abstract}
This study contains an analysis of mean monthly precipitation values, covering multiple profiles, in 13 Indian river catchment areas: Brahmaputra, Indus, Ganga, Mahi, Narmada, Tapti, Damodar, Brahmani, Krishna, Penner, Cauvery, Mahanadi and Godavari. The analysis covers data for the period 1901-2010 with a spatial resolution of $0.5^{\circ} x^{\circ} 0.5^{\circ}$ of geographic longitude and latitude (GPCC data). The data is analysed in monthly and calendar year profiles. The periodical nature of precipitation is assessed and the trends in climate changes calculated. The characteristics of trend in climate changes are described by linear equations with indicated boundary values of coefficients determined at a 5\% significance level. The analyses discussed confirm spatial and temporal variability of precipitation in the key river catchment areas in India, feeding the country's surface and underground water resources. The statistics contained in this study demonstrate the regional nature of water supply, indicate the need to complete regional analyses of temporal and spatial variations in the volumes of water feeding Indian resources, and confirm that regional and local plans must be developed to adapt to climate change, based on the accepted scenarios aimed to compensate climate change effects.
\end{abstract}

Keywords: GPCC data, monthly precipitation, annual precipitation, frequency analysis, climate trend in precipitation, territory of India.

\section{Introduction}

This study aims at supplementing necessary information about the characteristics of long-lasting precipitation series, precipitation total and mean values in the areas of surface water catchment areas of key importance for the feeding of Indian water resources. The study is focused on regional analyses showing clear interrelations between precipitation structures and volumes and the resultant effects in parts of river basins, distinguished areas in a hydrographic system or local drainage areas. The need to complete such analyses is emphasised in the reports prepared under the United Nations Framework Convention ${ }^{2}$ on Climate Change that provide a basis for scenarios developed to compensate climate change effects.

The detailed knowledge of precipitation volumes reaching the Earth land surface is particularly important for an assessment of the quantity of fresh water available, for water management as necessary to meet the demand for water and to mitigate the risks of floods and draughts. There is a growing body of scientific evidence confirming the hypothesis proposing climate changes caused by human activities. The intensity of those changes depends on the region and varies in time and space. The analyses of climate changes at a regional level demonstrate a strong correlation with anthropogenic impacts. The climate changes observed are characterised by shortened period of high-intensity precipitation and more frequent periods of long-lasting precipitation that cause great floods. Also the periods characterised by high temperatures and reduced precipitation have become longer. The polarization of extreme phenomena is an established fact, associated with the variations in and intensity of human activities. This study contains the results of my analyses of GPCC data for selected Indian river catchment areas. The approach used in the analyses enabled the author to characterize and estimate certain changes in the process of feeding the water resources available in selected Indian river catchment areas, resulting from variability of precipitation.

The water resources development programme implemented following India independence resulted in an increase in the available irrigation potential by five times, a progress was also reported in supplies of potable water and water for industrial purposes. However, the population growth rate, urbanization and industrial development have resulted in a significant increase in water demand and consumption. Extensive policies followed in some regions have led to excessive exploitation of available resources and consequently to durable

\footnotetext{
${ }^{1}$ Member of Advisory Board of Dronacharya College of Engineering, Gurgaon, India

${ }^{2}$ opened for signature on 5 June 1992 in Rio de Janeiro, ratified by Poland on 24 October 1994 (Journal of Laws Dz. U. No. 53 of 1996, item 238) 
Characteristics of long-term variability of precipitation in selected river catchment areas in India ..

depletion of water resources. Additionally, the growth of the industrial sector and a rapid urbanization process resulted in contamination of surface water and groundwater. The low efficiency of use of water intakes represents another problem in water management.

The total estimated volume of available resources reaches $4000 \mathrm{BCM}$; taking into account losses due to evaporation, an estimated total annual volume of available water amounts to $1869 \mathrm{BCM}$. However, considering the geomorphological and hydrological conditions, only 1123 BCM may be effectively used, including $61 \%$ from surface water and about 39\% from renewable groundwater resources. Attention should be paid to significant spatial and temporal differences in access to water. The Ganga and Brahmaputra river basins are characterised by the highest availability rates reaching about $60 \%$ of total annual volume of available water.

The government strategy implemented by the Ministry of Water Resources in India pays particular attention to an increase in the demand for water by about $20 \%$ over the next 10 years and by about $70 \%$ over the next 40 years, assessing the demand by the year 2050 at $1180\left[\mathrm{~km}^{3}\right]$ [BCM], compared to the current demand amounting to 700 [BCM]. These ambitious objectives, requiring considerable involvement of government and non-government institutions, open up another great growth opportunity to society of India. Social development achieved by education and qualification programmes carried out as part of the strategy may represent another desirable synergy outcome. Training programmes accompanying expenditures on infrastructure development are indispensable to improve the efficiency of use of water intakes.

Table 1. A statement of annual balances of water resources in India for the period $1901-2010$

\begin{tabular}{|c|c|c|c|c|c|c|c|c|c|c|c|}
\hline \multirow[t]{2}{*}{ Drainage area } & \multirow[t]{2}{*}{ Stations } & \multirow[t]{2}{*}{$\begin{array}{l}\text { GRDC_NO } \\
\text { river basin } \\
\text { ID }\end{array}$} & \multirow{2}{*}{$\begin{array}{c}\begin{array}{c}\text { Area } \\
\text { catchment }\end{array} \\
{\left[\mathrm{km}^{2}\right]}\end{array}$} & \multirow{2}{*}{$\begin{array}{c}\begin{array}{c}\text { Mean annual } \\
\text { precipitation }\end{array} \\
{[\mathrm{mm}]}\end{array}$} & \multirow{2}{*}{\begin{tabular}{|c|}
$\begin{array}{l}\text { Precipitation } \\
\text { volume }\end{array}$ \\
{$\left[\mathrm{km}^{3}\right]$}
\end{tabular}} & \multirow{2}{*}{$\begin{array}{c}\text { Trend } \\
\text { [mm/year] }\end{array}$} & \multirow{2}{*}{$\begin{array}{c}\begin{array}{c}\text { Trend } \\
{[\mathrm{mln}} \\
\left.\mathrm{m}^{3}\right]\end{array} \\
{\left[\mathrm{million}^{3} / \text { ivear }\right.} \\
\mathrm{m}^{2} / \text { yer }\end{array}$} & \multirow{2}{*}{\begin{tabular}{|c|}
$\begin{array}{c}\text { Mean } \\
\text { outflow for } \\
\text { the long-term } \\
\text { period }\end{array}$ \\
{$\left[\mathrm{m}^{3} / \mathrm{s}\right]$} \\
\end{tabular}} & \multirow{2}{*}{$\begin{array}{c}\begin{array}{c}\text { Runoff } \\
\text { coefficient for the } \\
\text { long-term period }\end{array} \\
{[]}\end{array}$} & \multicolumn{2}{|c|}{$\begin{array}{l}\text { Forecast change in } \\
\text { precipitation volume }\end{array}$} \\
\hline & & & & & & & & & & $\begin{array}{c}15 \text { years } \\
{\left[\mathrm{km}^{3}\right]}\end{array}$ & $\begin{array}{c}25 \text { years } \\
{\left[\mathrm{km}^{3}\right]}\end{array}$ \\
\hline BRAHMAPUTRA & BAHADURABAD & 2651100 & 505270.6 & 1532.59 & 774.4 & -0.1590 & -80.36 & 2826.4 & 0.238 & -1.205 & -2.009 \\
\hline INDUS & KOTRI & 2335950 & 1125733.6 & 450.61 & 507.3 & 0.0134 & 15.04 & 12111.8 & 0.409 & 0.226 & 0.376 \\
\hline GANGES & FARAKKA & 2846800 & 901751.6 & 1118.70 & 1008.8 & -0.0333 & -30.05 & 384.3 & 0.435 & -0.451 & -0.751 \\
\hline MAHI RIVER & SEVALIA & 2853150 & 35896.8 & 827.48 & 29.7 & 0.0601 & 2.16 & 1223.5 & 0.376 & 0.032 & 0.054 \\
\hline NARMADA & GARUDESHWAR & 2853200 & 88075.9 & 1148.46 & 101.2 & 0.0436 & 3.84 & 491.9 & 0.293 & 0.058 & 0.096 \\
\hline TAPTI RIVER & KATHORE & 2853300 & 64098.8 & 859.15 & 55.1 & 0.1356 & 8.69 & 298.3 & 0.381 & 0.130 & 0.217 \\
\hline \begin{tabular}{|l} 
DAMODAR RIVER \\
\end{tabular} & RHONDIA & 2854050 & 20413.2 & 1284.36 & 26.2 & 0.0385 & 0.79 & no data & no data & 0.012 & 0.020 \\
\hline $\begin{array}{l}\text { BRAHMANI RIVER } \\
\text { (BHAHMANI) }\end{array}$ & BARKOT BR. & 2854080 & 30090.1 & 1515.30 & 45.6 & -0.0239 & -0.72 & 1657.5 & 0.250 & -0.011 & -0.018 \\
\hline KRISHNA & \begin{tabular}{|l|} 
VIJAYAWADA \\
\end{tabular} & 2854300 & 255880.4 & 831.12 & 212.7 & 0.0648 & 16.59 & 74.5 & 0.067 & 0.249 & 0.415 \\
\hline \begin{tabular}{|l} 
PENNER RIVER \\
\end{tabular} & NELLORE & 2854500 & 54737.8 & 663.07 & 36.3 & 0.0450 & 2.47 & 207.8 & 0.087 & 0.037 & 0.062 \\
\hline CAUVERY RIVER & \begin{tabular}{|l|} 
GRAND ANICUT \\
\end{tabular} & 2854800 & 70315.9 & 1014.09 & 71.3 & -0.0138 & -0.97 & 1883.4 & 0.323 & -0.015 & -0.024 \\
\hline $\begin{array}{l}\text { MAHANADI RIVER } \\
\text { (MAHAHADI) }\end{array}$ & KAIMUNDI & 2855800 & 118002.2 & 1390.58 & 164.1 & -0.0307 & -3.62 & 3061.1 & 0.281 & -0.054 & -0.090 \\
\hline GODAVARI & \begin{tabular}{|l|} 
POLAVARAM \\
\end{tabular} & 2856900 & 309378.3 & 1145.78 & 354.5 & 0.0449 & 13.90 & 21545.2 & 0.697 & 0.208 & 0.347 \\
\hline \begin{tabular}{|l|} 
INDIA \\
\end{tabular} & & & 3287590.0 & 1126.68 & 3704.1 & 0.0206 & 67.72 & & & 1.016 & 1.693 \\
\hline
\end{tabular}

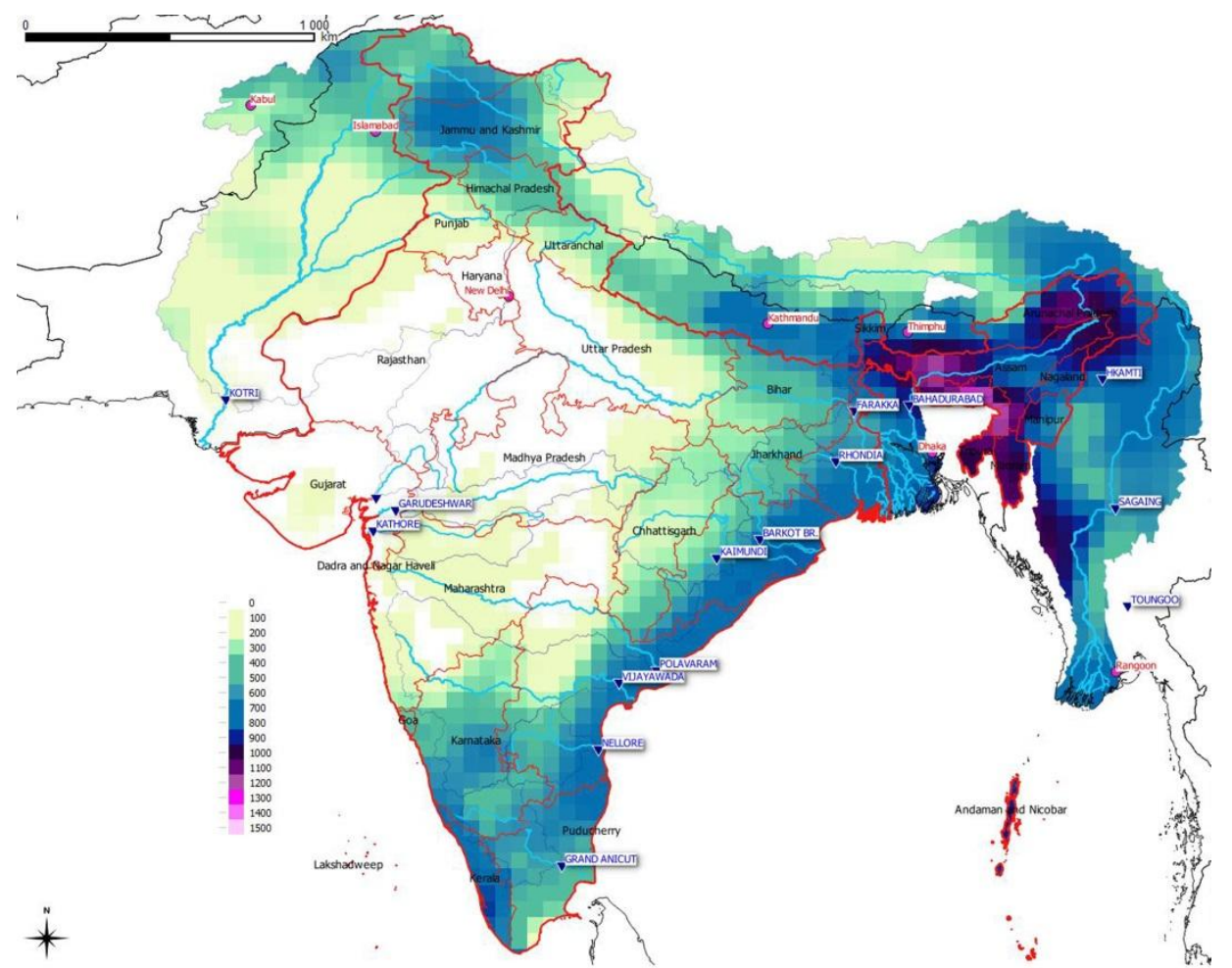

Figure 1. GPCC gauge-based gridded monthly precipitation data for the territory of India, [mm] May 2010 


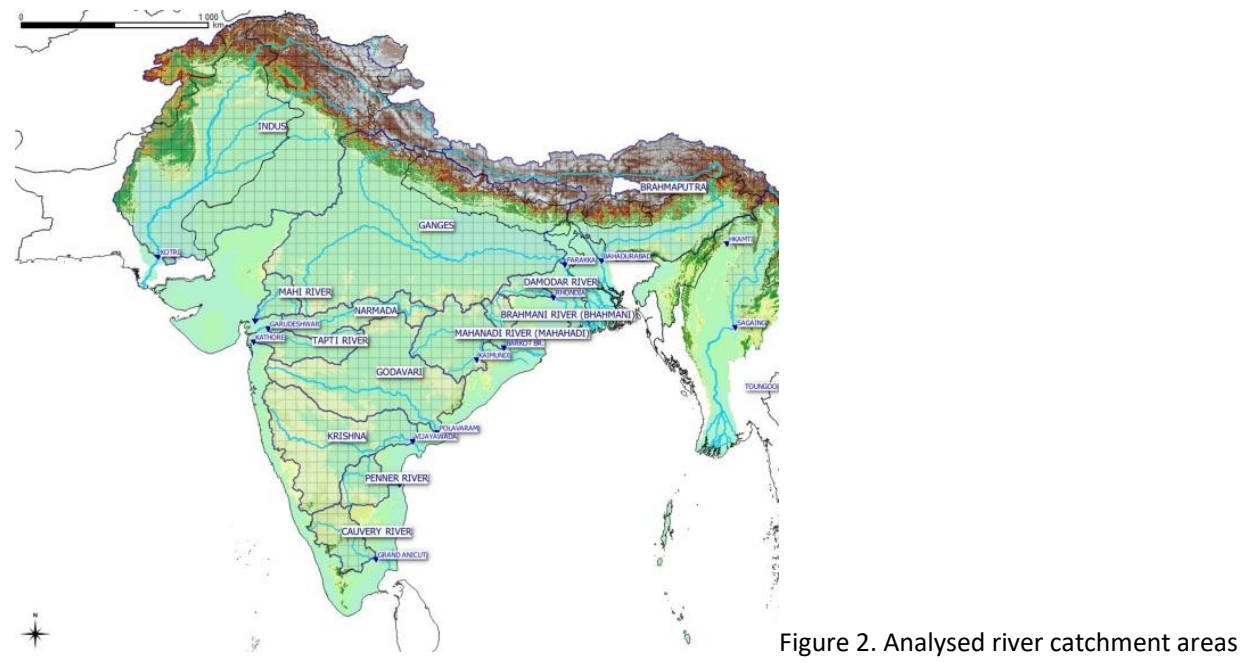

\section{The role of GPCC Precipitation Climatology Centre in collecting and providing precipitation data}

The Global Precipitation Climatology Centre(GPCC) was established in 1989 by the World Meteorological Organization (WMO). The Centre is supported and operated by the DeutscherWetterdienst (DWD, the German Meteorological Office) as a German contribution to the World Climate Research Programme (WCRP). The main objective of the GPCC is a global analysis of monthly precipitation on Earth land surface based on data provided by "in-situ" precipitation stations. In 1994, GPCC was requested by the WMO to support climate monitoring activities carried out by the Global Climate Observing System (GCOS). The GPCC has joined the GCOS network (GSNMC) in 1999, focusing on atmospheric precipitation while temperature monitoring is conducted by the Japan Meteorological Agency (JMA)

The objective of the GPCC is to meet the users' demand for accurate analyses, current and readily available datasets. For example: The WCRP, as part of the Global Energy and Water Cycle Exchanges Project (GEWEX), requires high spatial resolution and accuracy of data for the last two decades while the priorities of the GCOS and IPCC focus on long-term uniformity of time series showing climate changes. All GPCC products represent gridded near and non-real-time datasets of precipitation on the Earth land surface. Only monthly data is made available in spatial resolutions $0.5^{\circ} \mathrm{x} 0.5^{\circ}$ to $2.5^{\circ} \mathrm{x} 2.5^{\circ}$ of geographic longitude and latitude. The datasets are made available on the Internet (http://gpcc.dwd.de). The products are developed based on complete sets of information from the world precipitation database originating from more than 97000 stations that provide protected and classified raw records.

\section{Characteristics of data for 1901-2010}

The GPCC data representing total precipitation volumes in individual months in the period 1901-2010, with a spatial resolution of $0.5^{\circ} \times 0.5^{\circ}$ of geographic longitude and latitude, are converted to the analysed Indian drainage basin and key analysed river catchment areas. Thus a sequence of monthly precipitation values was obtained that is analysed in this study. The GIS interpolation methods are used in the spatial analysis of data. The calculated sequence values were subject to a simple statistical analysis in order to determine the basic statistics: the minimum and maximum values, the mean value, standard deviation of the sample and the value of the coefficient of variation. The data is analysed in calendar year profiles. The analyses of monthly precipitation values cover the years 1901-2010.

\section{An assessment of accuracy of the GPCC data for the period 1901-2010}

An analysis of error in monthly and annual values of total precipitation for the entire territory of India was completed to verify the data. The period subject to verification based on comparative data includes the years 1901-2010. The results of the analysis are shown in a graphic format. The relative error in the analysed total monthly precipitation values amounted on average from $(-1 \%)$ in July to $27 \%$ in November, resulting in a $4 \%$ mean value of relative error for the total of annual precipitation.

Table 2. Values of relative errors in the long-term period 1901-2010 in individual months, the territory of India

\begin{tabular}{|c|c|c|c|c|c|c|c|c|c|c|c|c|}
\hline Months & JAN & FEB & MAR & APR & MAY & JUN & JU & AUG & SEP & OCT & NOV & DEC \\
\hline Mean realtive error & $4 \%$ & $7 \%$ & $11 \%$ & $8 \%$ & $8 \%$ & $8 \%$ & $1 \%$ & $0 \%$ & $-1 \%$ & $11 \%$ & $27 \%$ & $22 \%$ \\
\hline
\end{tabular}

The positive value of error indicates underestimated totals of monthly precipitation published by the GPCC, compared to the precipitation values officially published in materials of the India Meteorological Department [2] 
Characteristics of long-term variability of precipitation in selected river catchment areas in India ..

Table 3. A statement of precipitation total values and selected statistics for the long-term period 1901-2010 in the territory of India

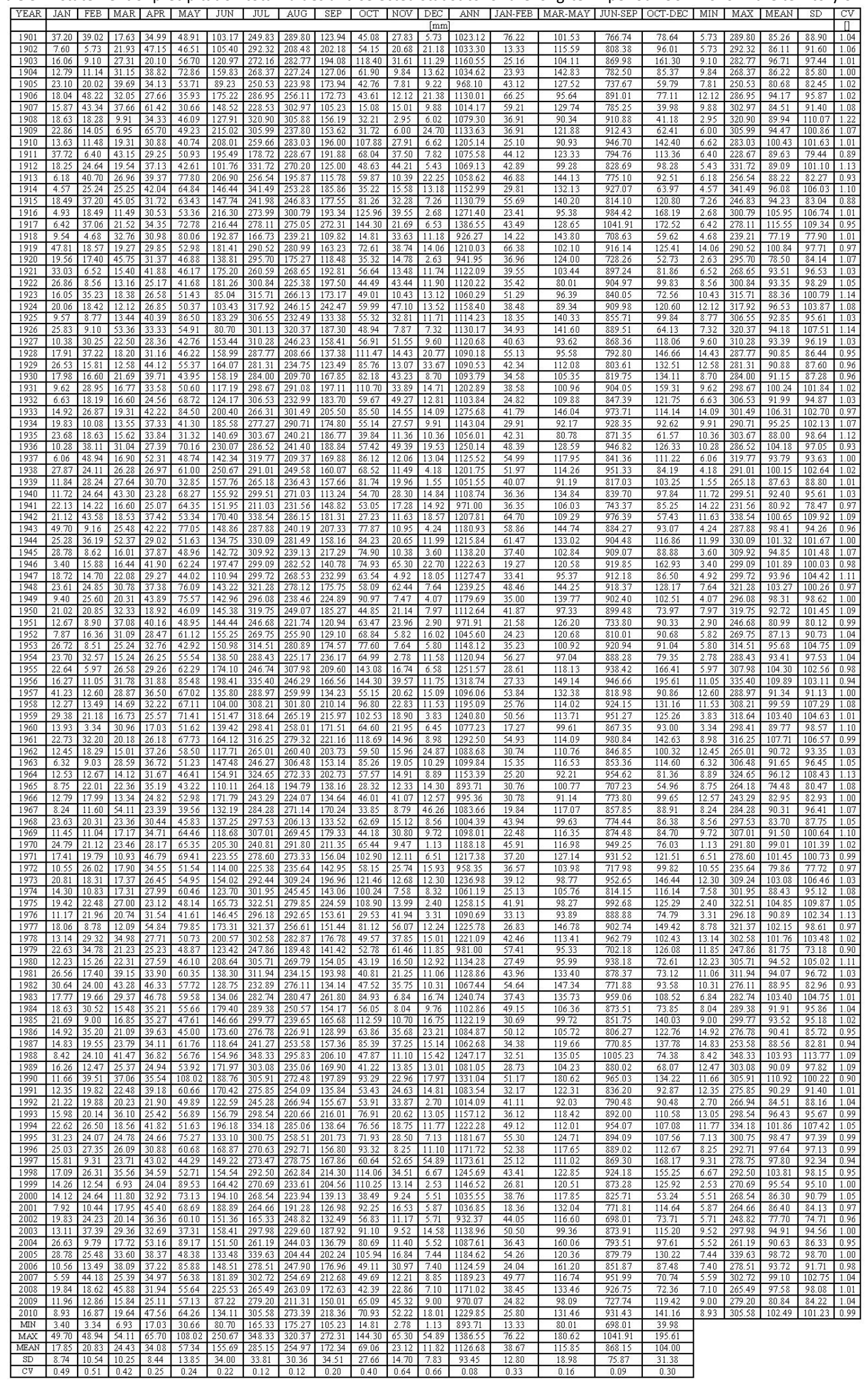




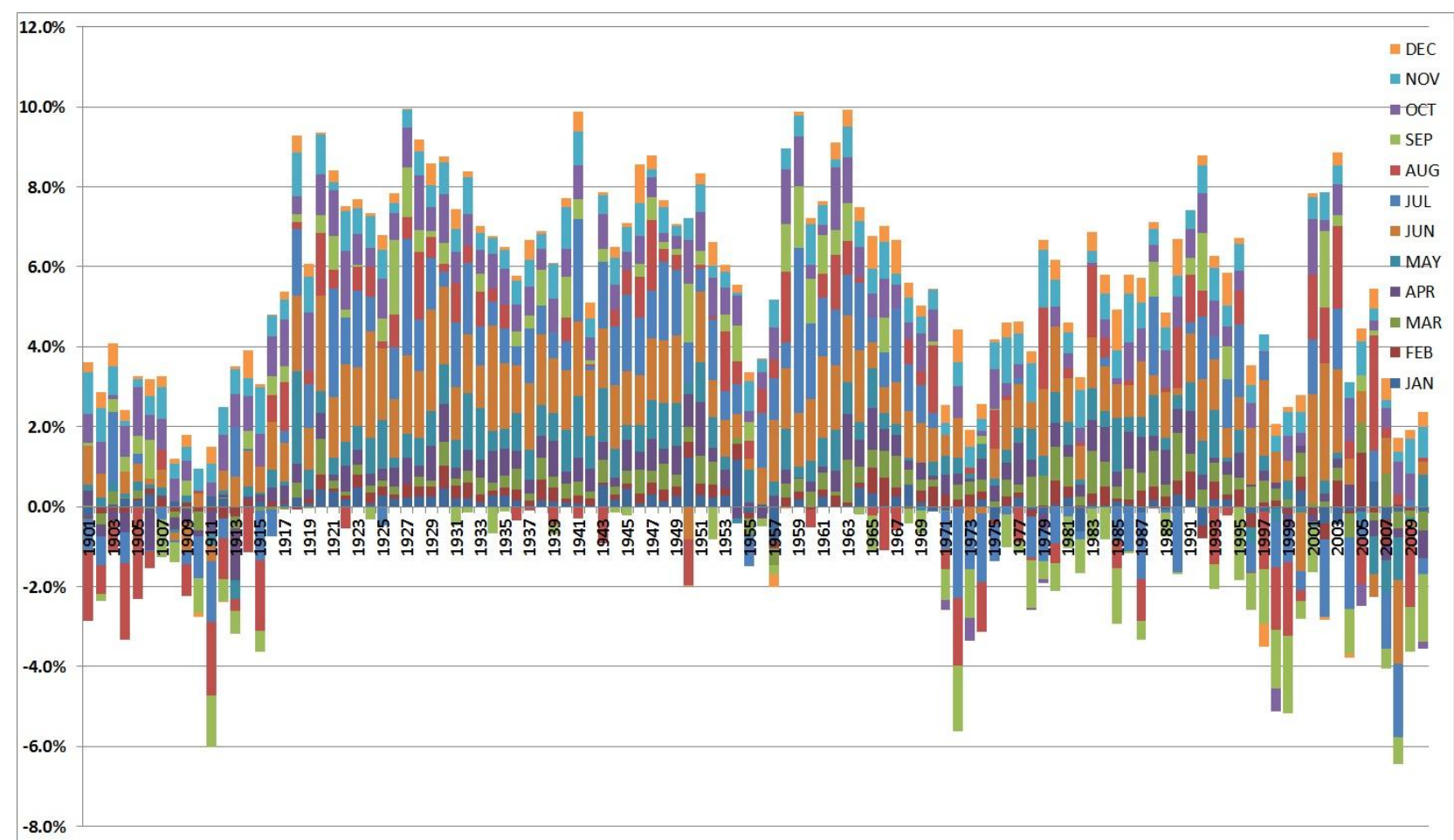

Figure 3. The structure of error in monthly precipitation values relative to the annual total, monthly precipitation values compared with the GPCC data [mm], the years 1901-2010, the territory of India

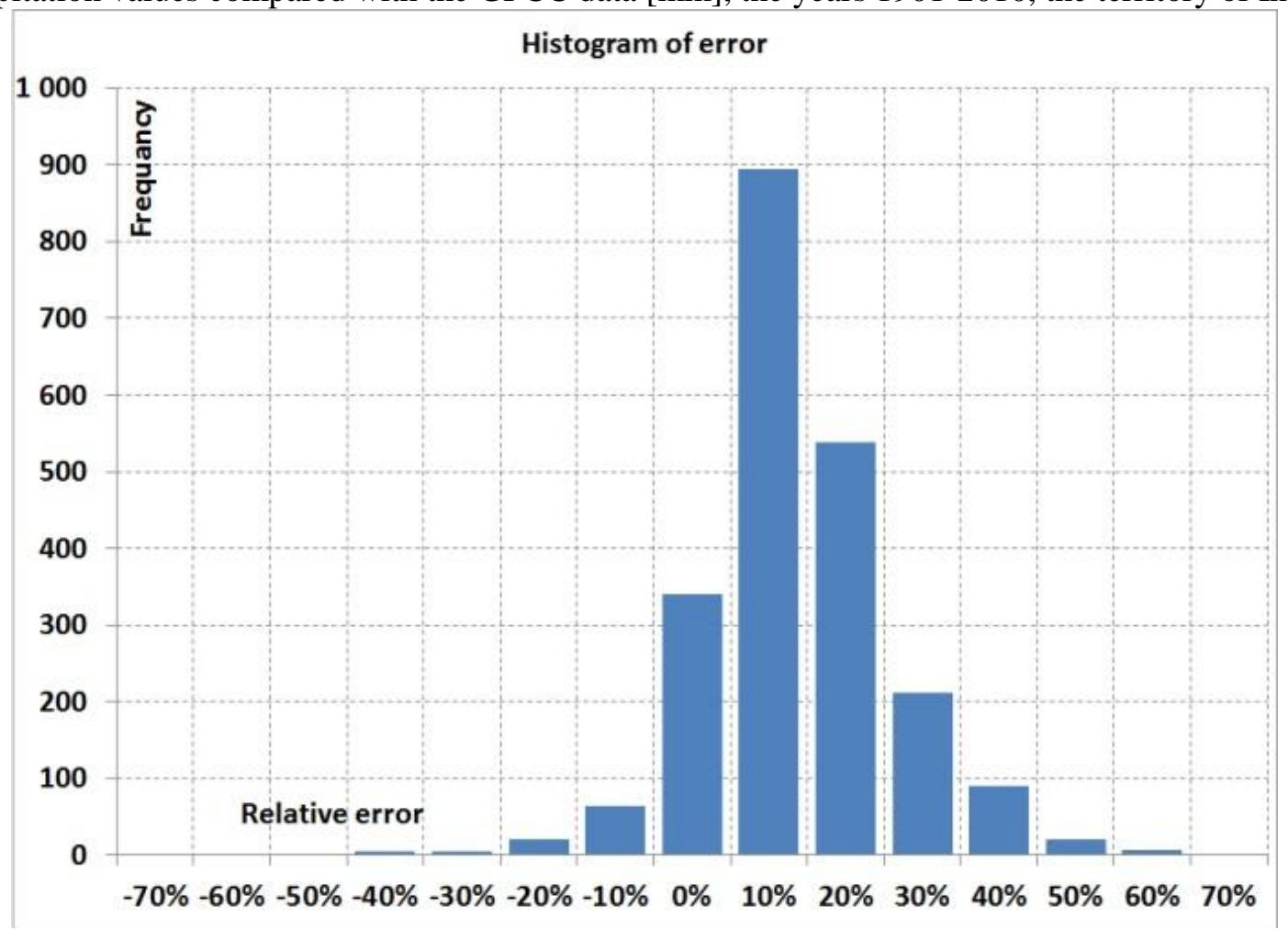

Figure 4. Histogram of relative error in monthly precipitation totals, the territory of India

V. Precipitation variability in the territory of India

A long-term mean annual total of precipitation based on the analyses is estimated at $1126 \mathrm{~mm}$ in India. The mean values in the analysed period of 110 years vary from $894 \mathrm{~mm}$ to $1387 \mathrm{~mm}$, with the largest volume of precipitation in India amounting to about $11690 \mathrm{~mm}$ - in Mawsynram near Cherrapunji in the state of Meghalaya in north-eastern India (R. Kumar, R. D. Singh and K. D. Sharma, 2005). On the other hand, in Jaisalmer in the Thar Desert in Rajasthan, the annual precipitation volume is as low as $150 \mathrm{~mm}$. $75 \%$ of total 
Characteristics of long-term variability of precipitation in selected river catchment areas in India ..

annual precipitation is recorded in the period from June to September. $750 \mathrm{~mm}$ of rain p.a. falls on about $21 \%$ of the India territory, and the total of annual precipitation exceeds $1500 \mathrm{~mm}$ on about $15 \%$ of the territory. The areas characterised by low volumes of precipitation, below $500 \mathrm{~mm}$, include the western region of Rajasthan, Gujarat, Haryana and Punjab, the interior of the Deccan Plateau east of Sahyadris and the region near Leh in Kashmir. The standard deviation of mean value of annual total precipitation reaches $10 \%$ and the coefficient of variation amounts to 0.08 . The sum of mean precipitation volume in the long-term period amounts to $3704 \mathrm{~km}^{3}$, showing a positive trend of 68 [million $\mathrm{m}^{3} /$ year].

\section{Precipitation periodicity in the territory of India}

The periodicity of precipitation in the territory of India was assessed using signal processing theory with a harmonic analysis applied. The procedures necessary to calculate the values of predominating frequencies were developed in Matlab. The inverses of those values represent the predominating period of repeatability of an event. The analysis was completed for various profiles of the analysed dataset. The results are shown in graphic and tabular formats.

The periodicity of monthly precipitation, considered using monthly profiles of calendar years in the analysed period 1901-2010, may be described as follows: November is characterised by a long predominating period of repeatability: 16 years while predominating periods of repeatability for the remaining months amount to 2 to 14 years. Period of repeatability of minimum values: 55 years, maximum values: 2 years, medium values: 2.5 years

\section{Premises for an analysis of climate changes observed in precipitation}

The trend in climate changes considered using monthly precipitation profiles for the calendar year is described by linear equations with indicated boundary values of coefficients determined at a $5 \%$ significance level. The slope values are both negative and positive for the analysed period 1901-2010. The months of January, February, April, August and December are characterised by a decreasing trend in precipitation while the remaining months by a positive trend. The values vary between -0.035 in August and +0.098 [mm/year] in October.
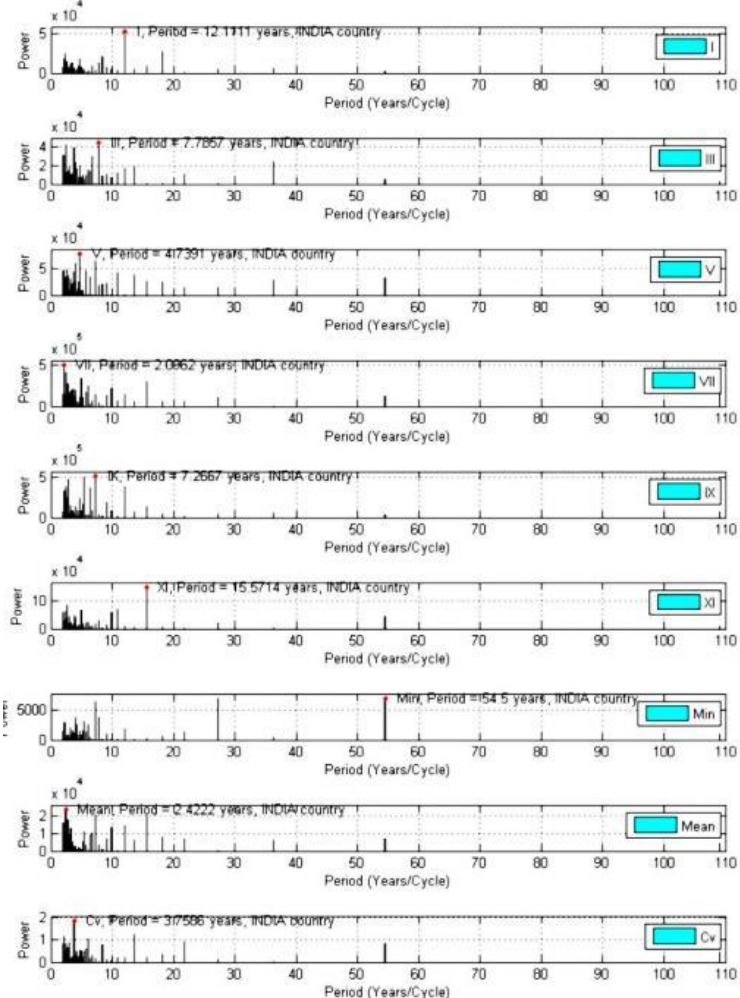

Figure 5. Inverses of predominating frequencies of monthly precipitation values and their statistics for the territory of India
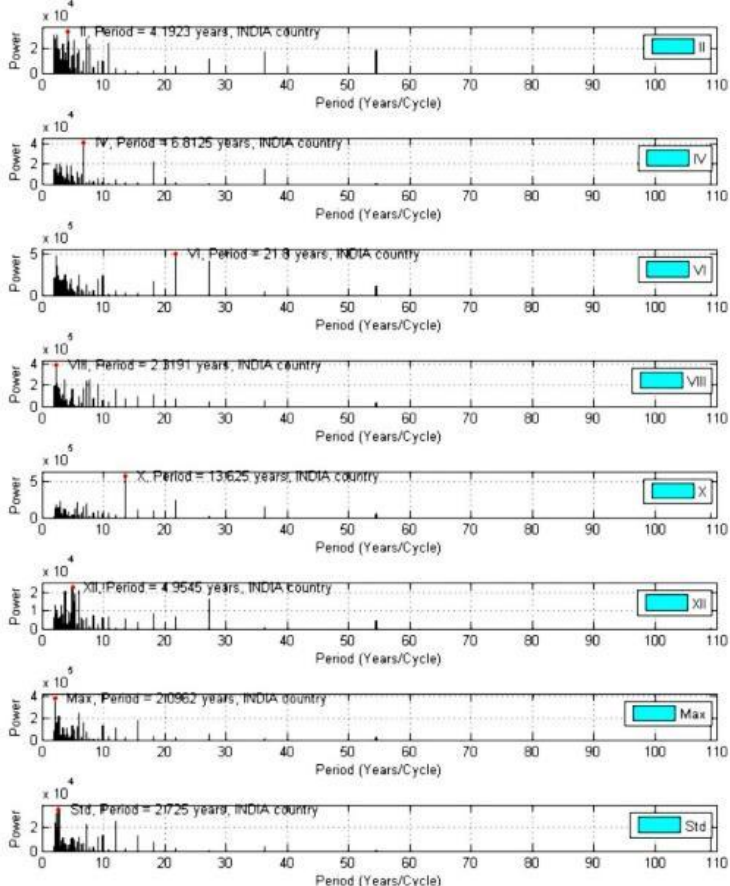
Characteristics of long-term variability of precipitation in selected river catchment areas in India ..

\section{Analyses of selected catchment areas \\ 1.1. GRDC data ${ }^{3}$}

The GRDC has created and manages a large bank of hydrological data, including watercourses, their topology, flows in selected water-level gauge locations, and catchment area boundaries on Earth. The GRDC website makes available both hydrographic and hydrological data. Access to the database is regulated by the Policy guidelines for the dissemination of data. This analysis uses GRDC data describing the catchment areas of rivers located in whole or in part in the territory of India, with closing cross-sections indicated.

\subsection{Application}

The monthly precipitation values for selected river catchment areas in the territory of India area are calculated using GIS interpolation methods. The GPCC data representing total precipitation volumes in individual months in the period 1901-2010, with a spatial resolution of $0.5^{\circ} \times 0.5^{\circ}$ of geographic longitude and latitude, converted to the analysed river catchment areas. A sequence of monthly precipitation values was obtained and is analysed below, like in the analysis covering the territory of India. The calculated sequence values were subject to a simple statistical analysis in order to determine the basic statistics: the minimum and maximum values, the mean value, standard deviation of the sample and the value of the coefficient of variation. The data is analysed in calendar year profiles. The analyses of monthly precipitation values cover the years 1901-2010.

The mean total of precipitation in the analysed river catchment areas in the long-term period varies from 1532 in the Brahmaputra catchment area to $450 \mathrm{~mm}$ in the Indus catchment area at coefficients of variation of 0.13 for the Brahmaputra river and of 0.17 for the Indus river. The greatest value of coefficient of variation in total annual precipitation in the analysed long-term period is observed in the catchment area of the Mahi river $(0.28)$ at a mean total of precipitation amounting to $827 \mathrm{~mm}$. The greatest mean values are recorded in the Brahmaputra catchment area and the lowest - in the Indus catchment area (about $314 \mathrm{~mm}$ ).

Table 4. A statement of periodicity values (inverses of predominating frequencies) for mean monthly precipitation sequences in the period 1901-2010 by months in the territory of India

\begin{tabular}{|c|c|c|c|c|c|c|c|c|c|c|c|c|c|c|c|c|c|}
\hline \multirow{3}{*}{ Analysed sequence profile } & \multicolumn{12}{|c|}{ Months of the calendar year } & \multicolumn{5}{|c|}{ Periodictivity statistics of } \\
\hline & 'I' & 'TI' & 'III' & 'TV' & $\mathrm{V}^{\prime}$ & 'VI' & 'VII' & 'VIII' & 'TX' & 'X' & 'XI' & 'XII' & MIN & MAX & MEAN & SD & $\mathrm{CV}$ \\
\hline & \multicolumn{17}{|c|}{ [years] } \\
\hline Predominating period in years & 12.111 & 4.192 & 7.786 & 6.813 & 4.739 & 21.800 & 2.096 & 2.319 & 7.267 & 13.625 & 15.571 & 4.955 & 54.500 & 2.096 & 2.422 & 2.725 & 3.759 \\
\hline
\end{tabular}

Table 5. Values of parameters of the linear trend in monthly precipitation in the analysed period for the territory of India

\begin{tabular}{|c|c|c|c|c|c|c|c|c|c|c|c|c|c|c|c|c|c|c|}
\hline & & \multicolumn{12}{|c|}{ Months of the calendar year } & \multicolumn{5}{|c|}{ Statistics of } \\
\hline & Units & $T^{\prime}$ & 'II' & 'III' & 'IV' & 'V' & 'VI' & 'VII' & 'VIII' & 'IX' & $\mathrm{X}^{\prime}$ & 'XI' & 'XII' & MIN & MAX & MEAN & SD & $\mathrm{CV}$ \\
\hline $\begin{array}{l}\text { Slope value } \\
a\end{array}$ & \multirow{3}{*}{ [mm/year] } & -0.022 & -0.011 & 0.006 & -0.010 & 0.086 & 0.026 & 0.047 & -0.035 & 0.065 & 0.098 & 0.000 & -0.002 & 0.009 & -0.015 & 0.021 & -0.006 & 0.000 \\
\hline $\begin{array}{l}\text { Lower limit } \\
\text { at a } 95 \% \text { confidence level }\end{array}$ & & -0.074 & -0.075 & -0.055 & -0.061 & 0.004 & -0.178 & -0.156 & -0.217 & -0.142 & -0.067 & -0.088 & -0.049 & -0.011 & -0.166 & -0.026 & -0.059 & -0.001 \\
\hline $\begin{array}{l}\text { Upper limit } \\
\text { at a } 95 \% \text { confidence level }\end{array}$ & & 0.031 & 0.052 & 0.068 & 0.040 & 0.167 & 0.230 & 0.250 & 0.147 & 0.272 & 0.263 & 0.088 & 0.045 & 0.029 & 0.137 & 0.067 & 0.046 & 0.000 \\
\hline $\begin{array}{l}\text { Coefficient value } \\
b\end{array}$ & \multirow{3}{*}{ [mm] } & 60.42 & 43.16 & 11.81 & 54.60 & -110.07 & 105.33 & 192.59 & 323.24 & 45.79 & -122.87 & 23.29 & 16.05 & -9.34 & 321.14 & 53.61 & 108.01 & 1.62 \\
\hline $\begin{array}{l}\text { Lower limit } \\
\text { at a } 95 \% \text { confidence level }\end{array}$ & & -41.90 & -80.65 & -108.62 & -44.49 & -269.58 & -293.92 & -204.22 & -33.24 & -358.85 & -445.69 & -149.38 & -75.92 & -48.84 & 24.56 & -37.55 & 5.02 & 0.92 \\
\hline $\begin{array}{l}\text { Upper limit } \\
\text { at a 95\% confidence level }\end{array}$ & & 162.74 & 166.96 & 132.24 & 153.69 & 49.44 & 504.59 & 589.39 & 679.72 & 450.43 & 199.96 & 195.96 & 108.02 & 30.16 & 617.72 & 144.77 & 211.01 & 2.32 \\
\hline
\end{tabular}

Table 6. Statistics of mean annual precipitation in the analysed river catchment areas in the period 1901-2010

\begin{tabular}{|l|l|l|c|c|c|c|c|c|}
\hline \multicolumn{1}{|c|}{ Drainage } & \multicolumn{1}{|c|}{ Station } & GRDC_NO & AREA & MIN & MAX & MEAN & SD & CV \\
\hline BRAHMAPUTRA & & & \multicolumn{3}{|c|}{$[\mathrm{mm}]$} & {$\left[\mathrm{km}^{2}\right]$} & \multicolumn{4}{|c|}{[]} \\
\hline INDUS & BAHADURABAD & 2651100 & 505270.6 & 1206 & 2235 & 1533 & 199 & 0.130 \\
\hline GANGES & KOTRI & 2335950 & 1125733.6 & 314 & 643 & 451 & 75 & 0.167 \\
\hline MAHI RIVER & FARAKKA & 2846800 & 901751.6 & 860 & 1448 & 1119 & 129 & 0.115 \\
\hline NARMADA & SEVALIA & 2853150 & 35896.8 & 341 & 1480 & 827 & 229 & 0.277 \\
\hline TAPTI RIVER & GARUDESHWAR & 2853200 & 88075.9 & 675 & 1690 & 1148 & 202 & 0.176 \\
\hline DAMODAR RIVER & KATHORE & 2853300 & 64098.8 & 409 & 1365 & 859 & 173 & 0.201 \\
\hline BRAHMANI RIVER (BHAHMANI) & BARKOT BR. & 2854080 & 30090.1 & 1054 & 2030 & 1515 & 199 & 0.131 \\
\hline KRISHNA & VIJAYAWADA & 2854300 & 255880.4 & 561 & 1186 & 831 & 126 & 0.151 \\
\hline PENNER RIVER & NELLORE & 2854500 & 54737.8 & 398 & 1084 & 663 & 141 & 0.213 \\
\hline CAUVERY RIVER & GRAND ANICUT & 2854800 & 70315.9 & 697 & 1340 & 1014 & 134 & 0.133 \\
\hline MAHANADI RIVER (MAHAHADI) & KAIMUNDI & 2855800 & 118002.2 & 885 & 1994 & 1391 & 197 & 0.142 \\
\hline GODAVARI & POLAVARAM & 2856900 & 309378.3 & 645 & 1635 & 1146 & 167 & 0.146 \\
\hline INDIA & & & 3287590.0 & 894 & 1387 & 1127 & 93 & 0.083 \\
\hline
\end{tabular}

\footnotetext{
${ }^{3}$ The GRDC operates under the auspices of the World Meteorological Organization (WMO) and is hosted by the Federal Institute of Hydrology (BfG) in Koblenz, Germany
} 
Characteristics of long-term variability of precipitation in selected river catchment areas in India ..

Table 7. A statement of total monthly precipitation [mm] and selected statistics for the long-term period 1901 2010 in the Brahmaputra river catchment areas

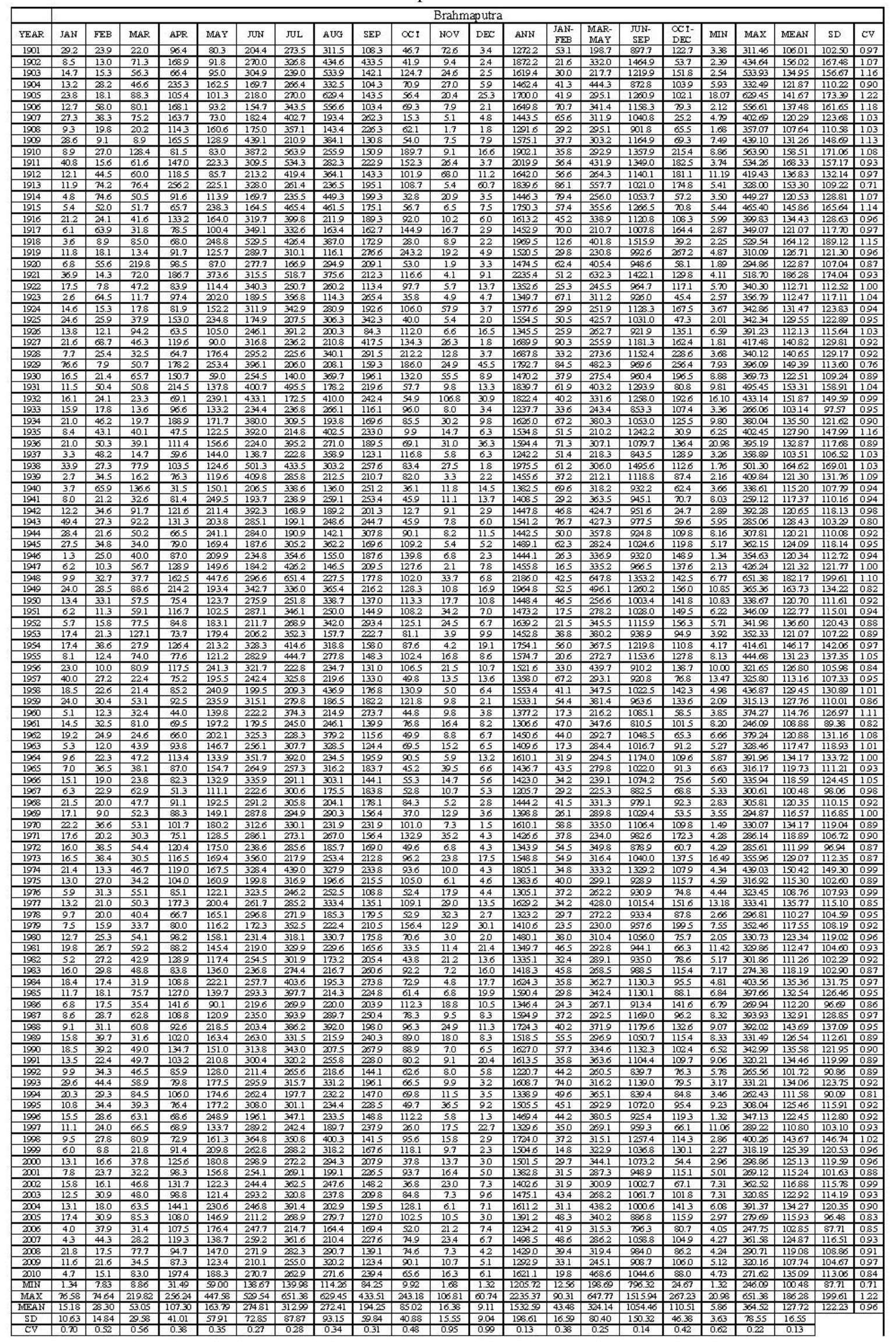


Characteristics of long-term variability of precipitation in selected river catchment areas in India ..

Table 8. A statement of total monthly precipitation [mm] and selected statistics for the long-term period $1901-$ 2010 in the Indus river catchment areas

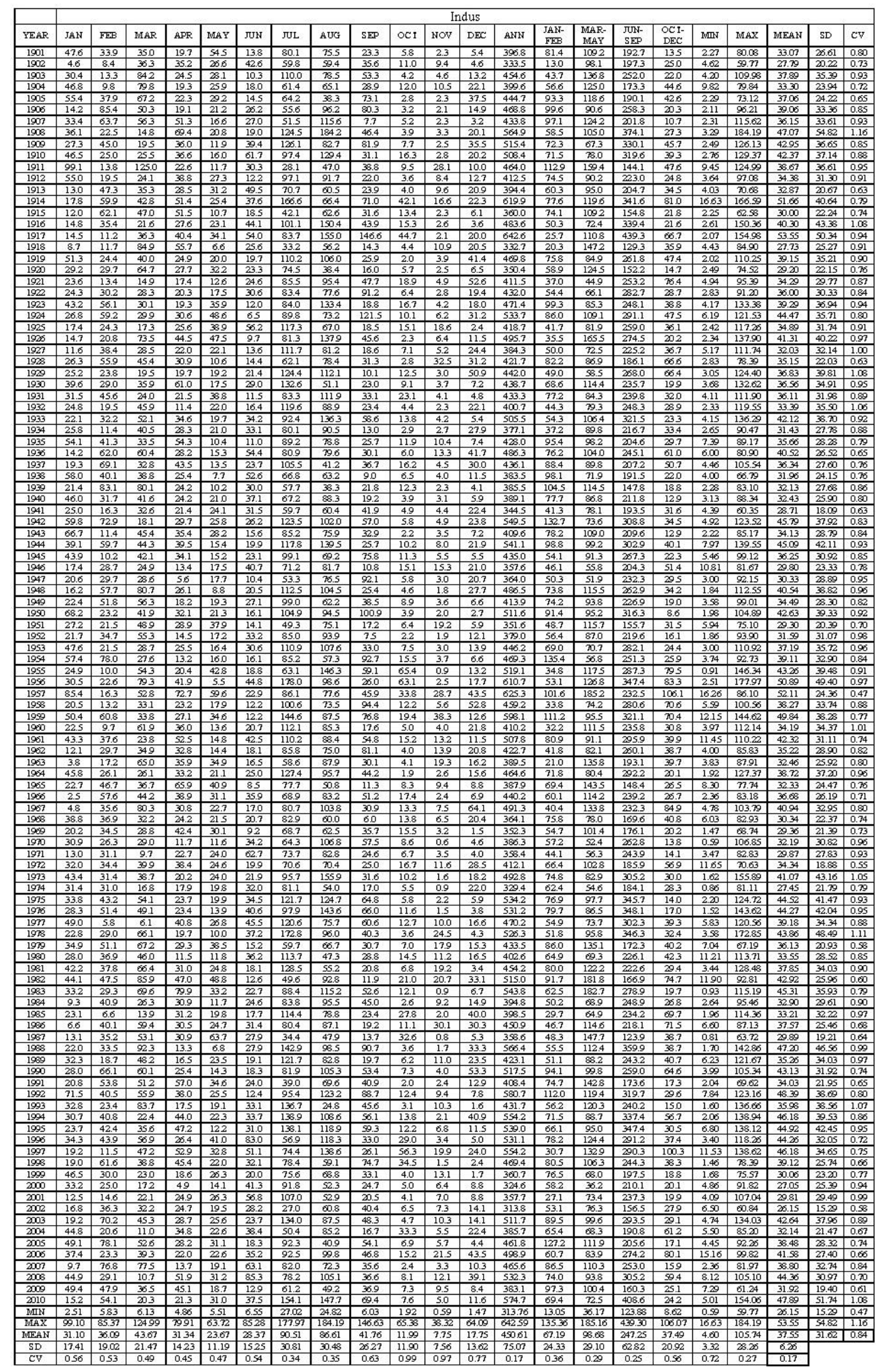


Characteristics of long-term variability of precipitation in selected river catchment areas in India ..

Table 9. A statement of total monthly precipitation [mm] and selected statistics for the long-term period $1901-$ 2010 in the Ganga river catchment areas

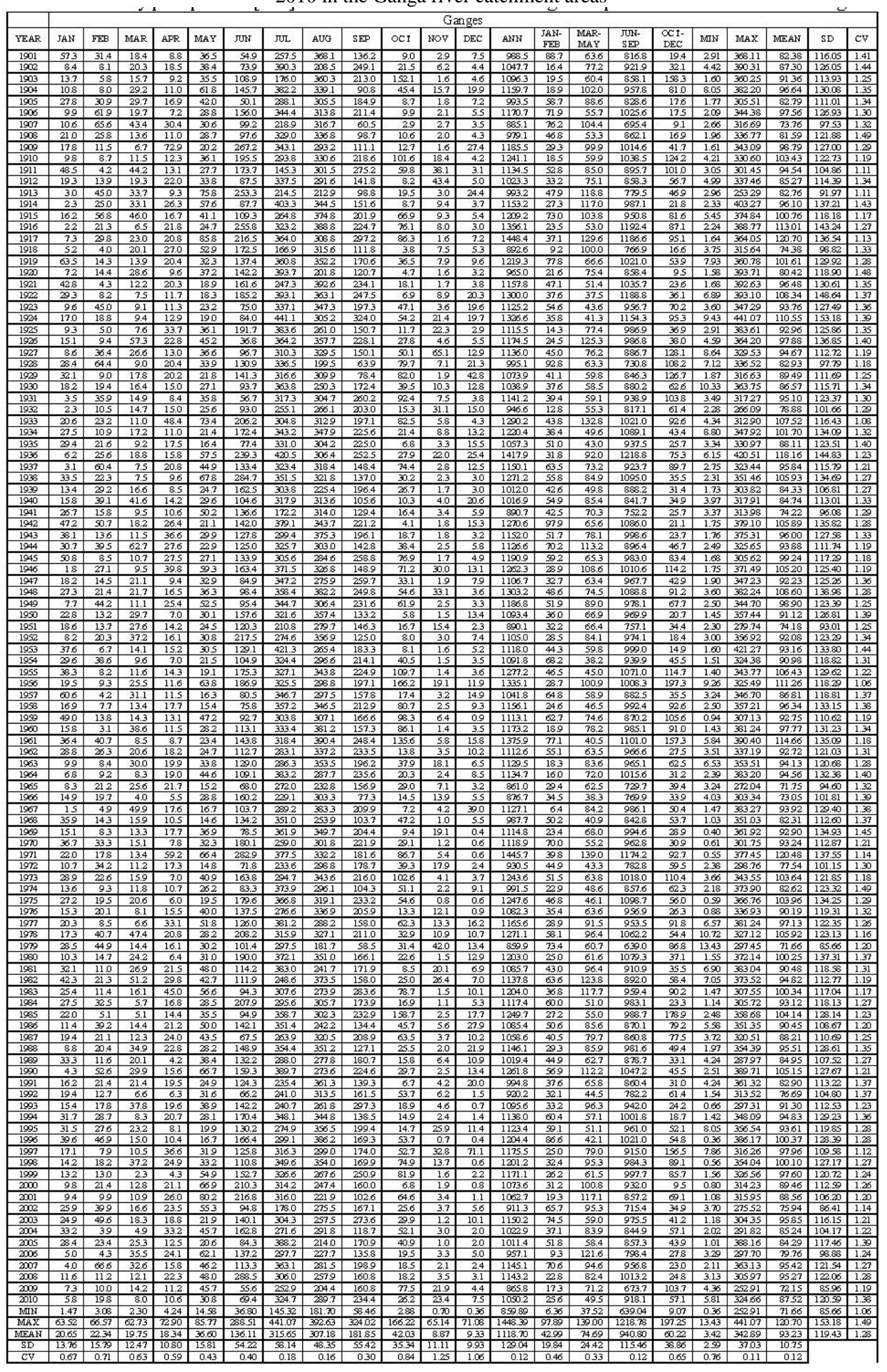


Characteristics of long-term variability of precipitation in selected river catchment areas in India ..

Table 10. A statement of total monthly precipitation $[\mathrm{mm}]$ and selected statistics for the long-term period 1901 -2010 in the Mahi river catchment areas




Characteristics of long-term variability of precipitation in selected river catchment areas in India ..

Table 11. A statement of total monthly precipitation $[\mathrm{mm}]$ and selected statistics for the long-term period 1901 2010 in the selected Narmada river catchment areas

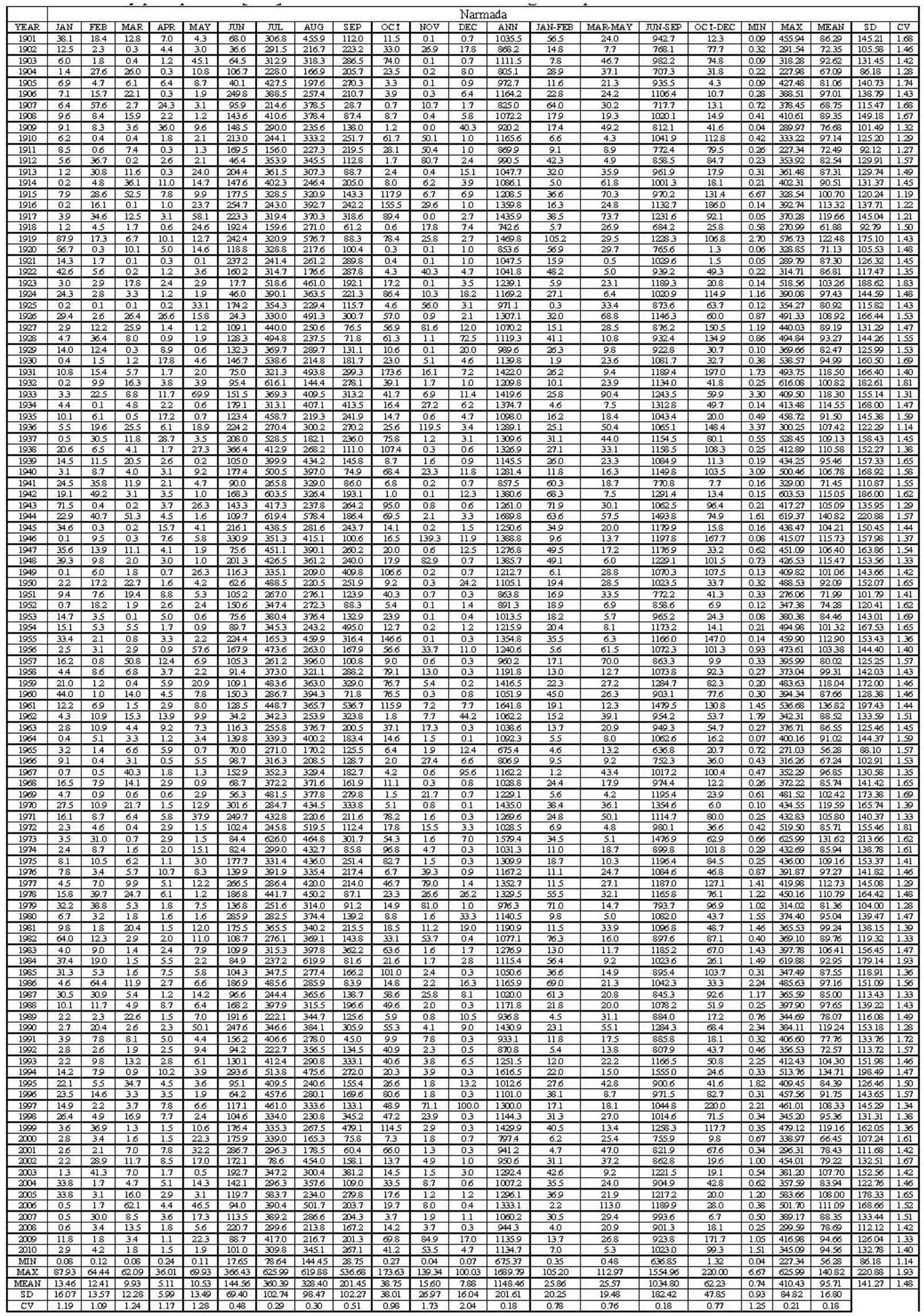




\section{Characteristics of long-term variability of precipitation in selected river catchment areas in India ..}

Table 12. A statement of total monthly precipitation $[\mathrm{mm}]$ and selected statistics for the long-term period 1901 2010 in the selected Tapti river catchment areas

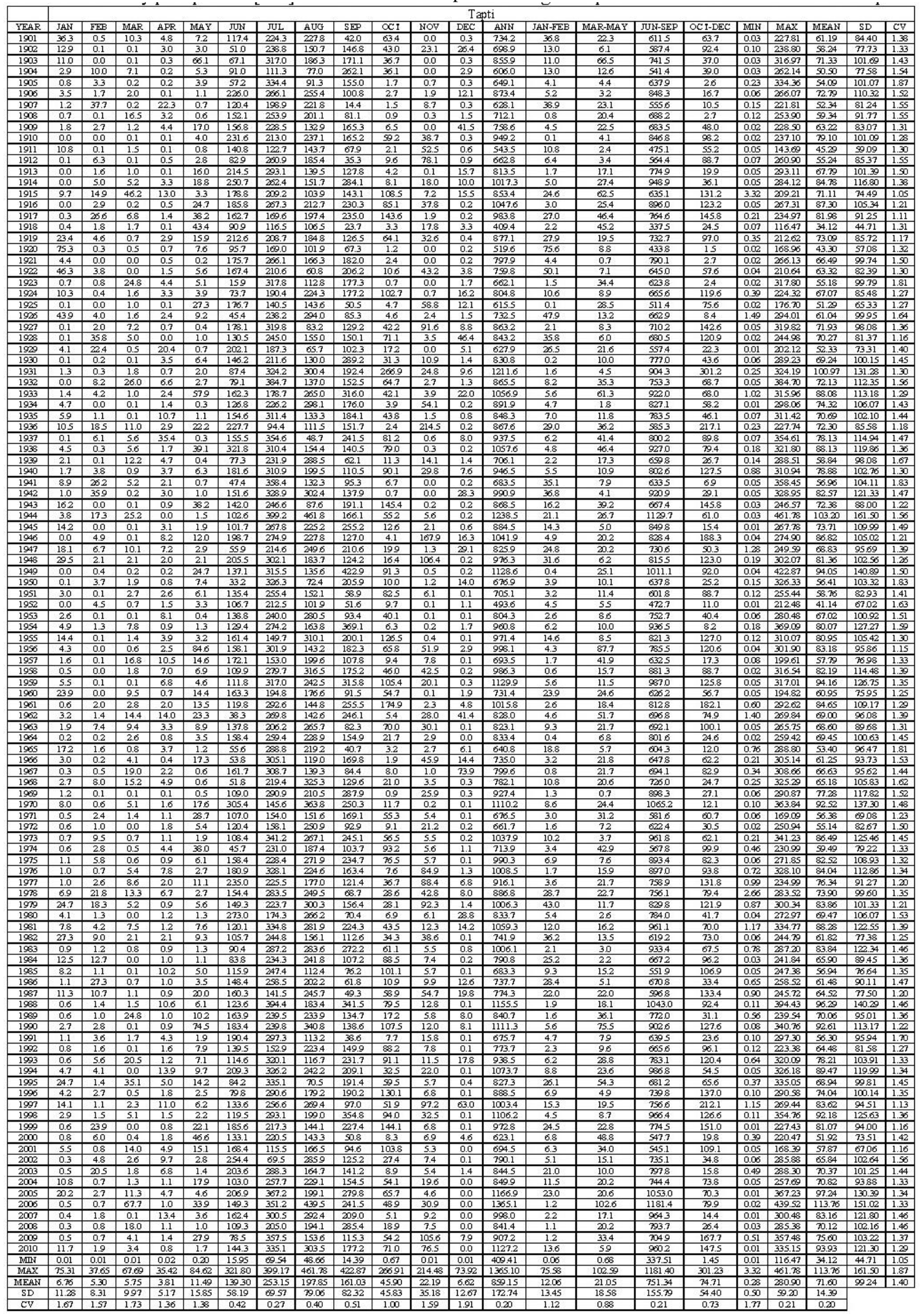


Characteristics of long-term variability of precipitation in selected river catchment areas in India ..

Table 13. A statement of total monthly precipitation $[\mathrm{mm}]$ and selected statistics for the long-term period 1901 - 2010 in the selected Damodar river catchment areas

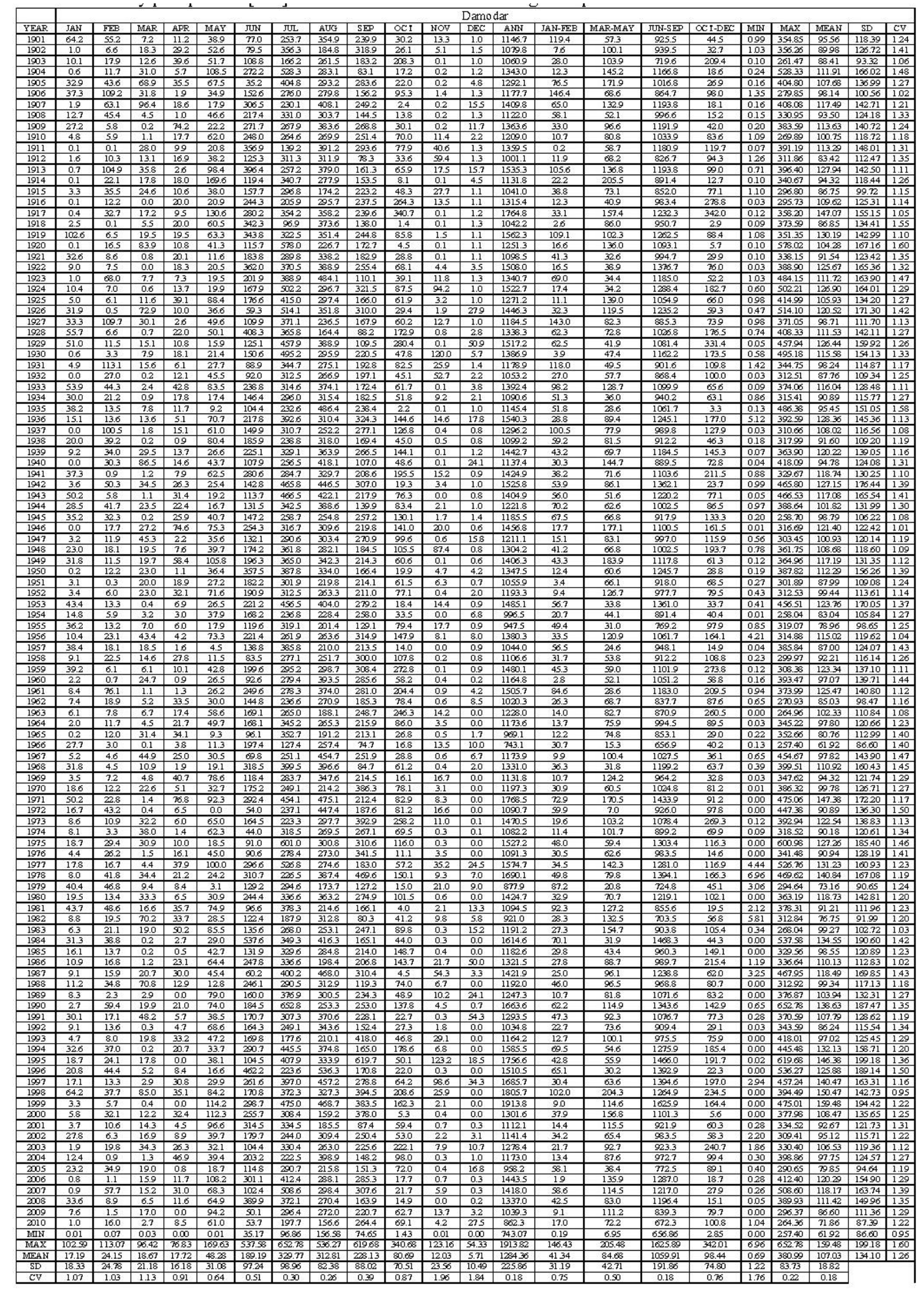


Characteristics of long-term variability of precipitation in selected river catchment areas in India ..

Table 14. A statement of total monthly precipitation $[\mathrm{mm}]$ and selected statistics for the long-term period 1901 -2010 in the selected Brahmani river catchment areas

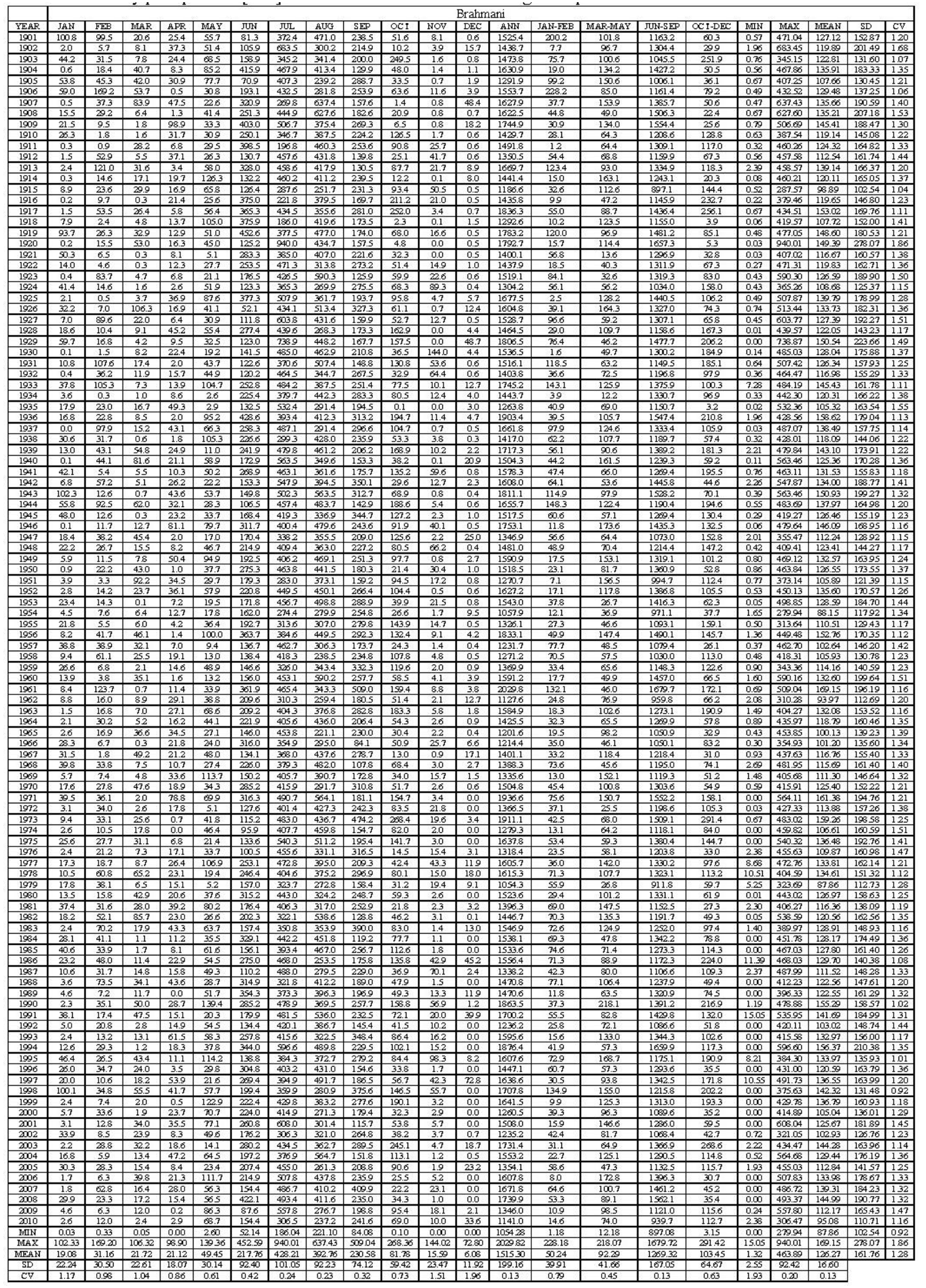


Characteristics of long-term variability of precipitation in selected river catchment areas in India ..

Table 15. A statement of total monthly precipitation $[\mathrm{mm}]$ and selected statistics for the long-term period 1901 2010 in the selected Krishna river catchment areas

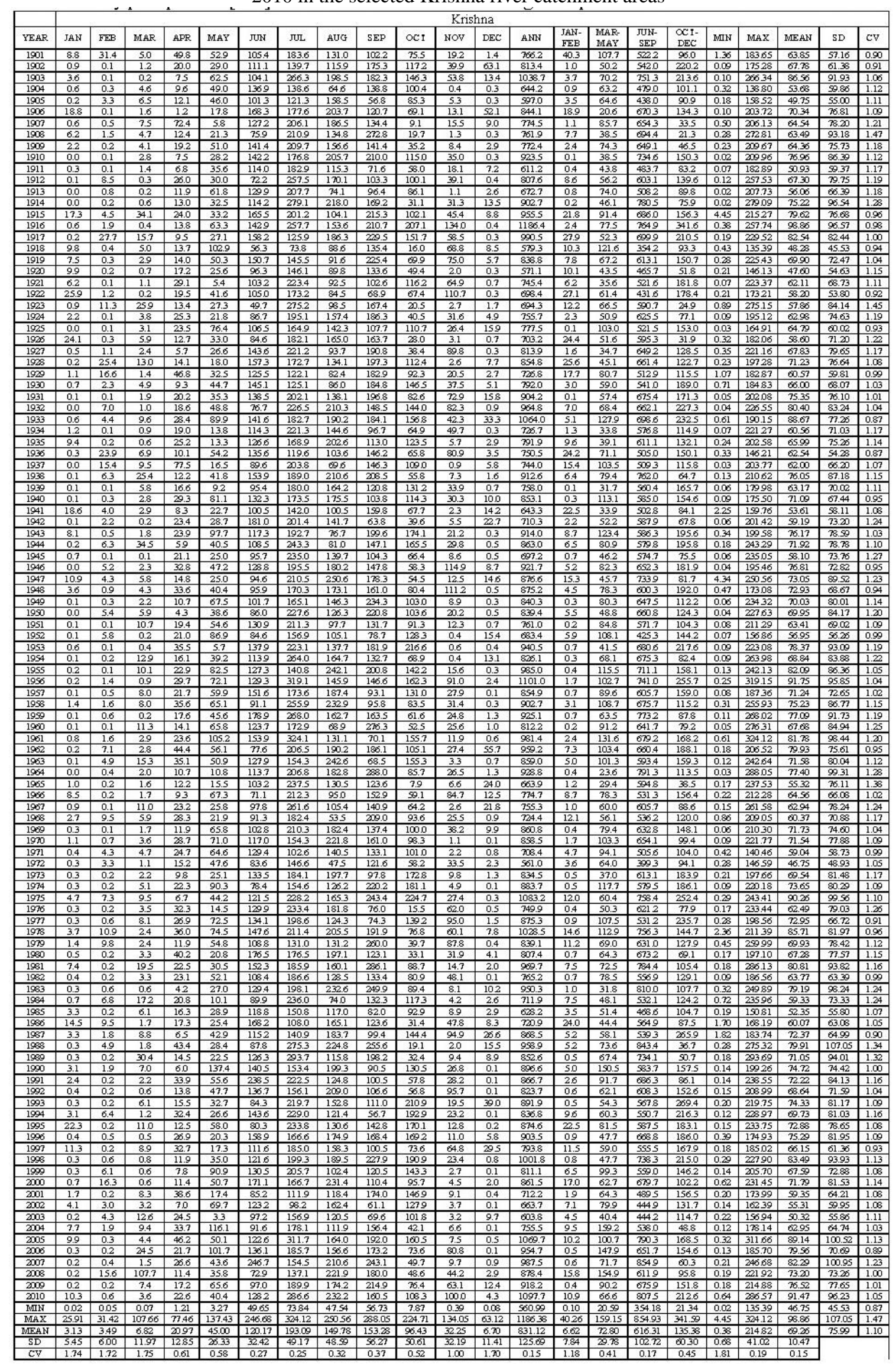


Characteristics of long-term variability of precipitation in selected river catchment areas in India ..

Table 16. A statement of total monthly precipitation $[\mathrm{mm}]$ and selected statistics for the long-term period 1901 ... . . $\quad-2010$ in the selected Penner river catchment areas

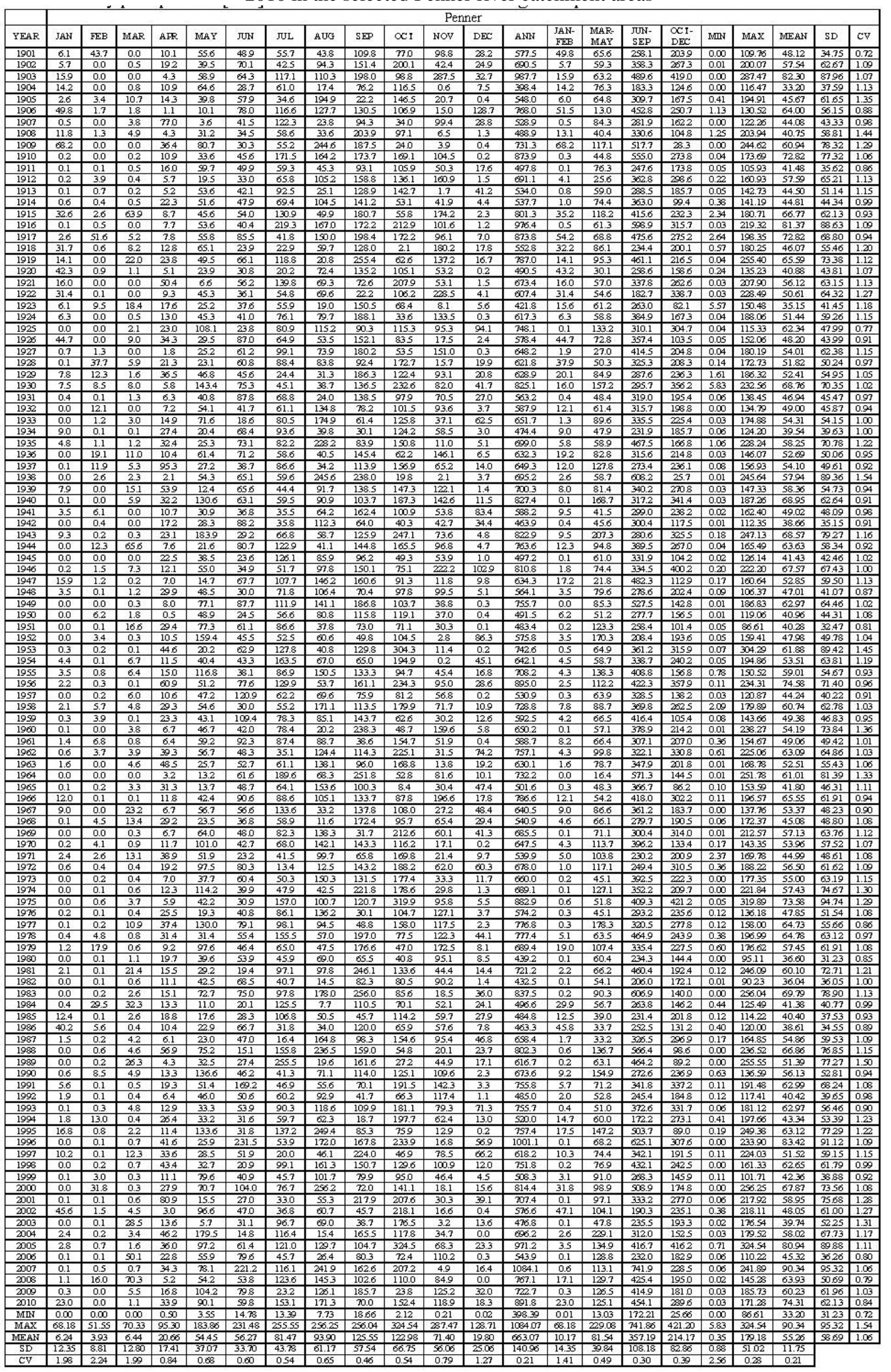


Characteristics of long-term variability of precipitation in selected river catchment areas in India ..

Table 17. A statement of total monthly precipitation $[\mathrm{mm}]$ and selected statistics for the long-term period 1901 -2010 in the selected Cauvery river catchment areas

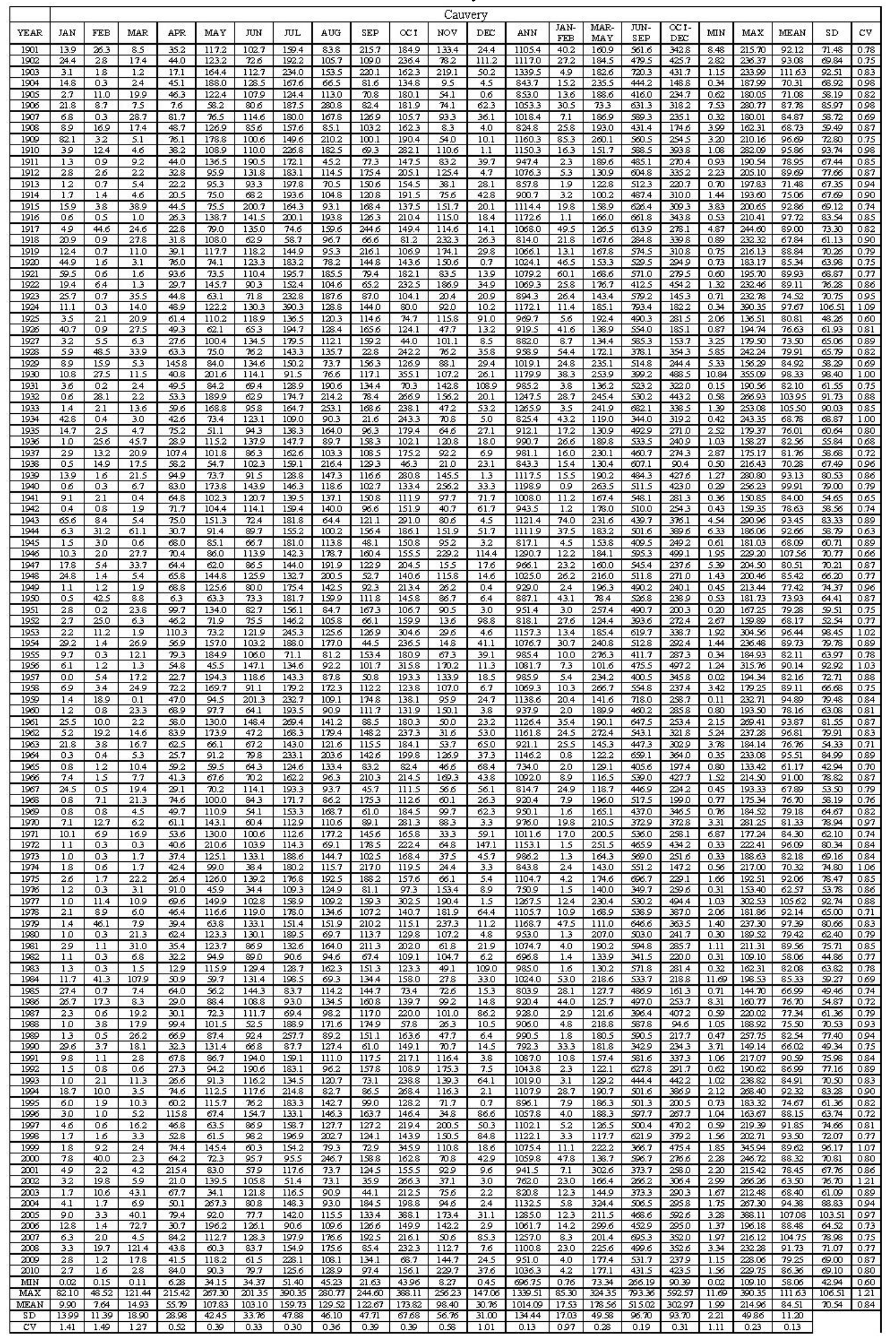


Characteristics of long-term variability of precipitation in selected river catchment areas in India ..

Table 18. A statement of total monthly precipitation $[\mathrm{mm}]$ and selected statistics for the long-term period 1901 -2010 in the selected Mahanadi river catchment areas

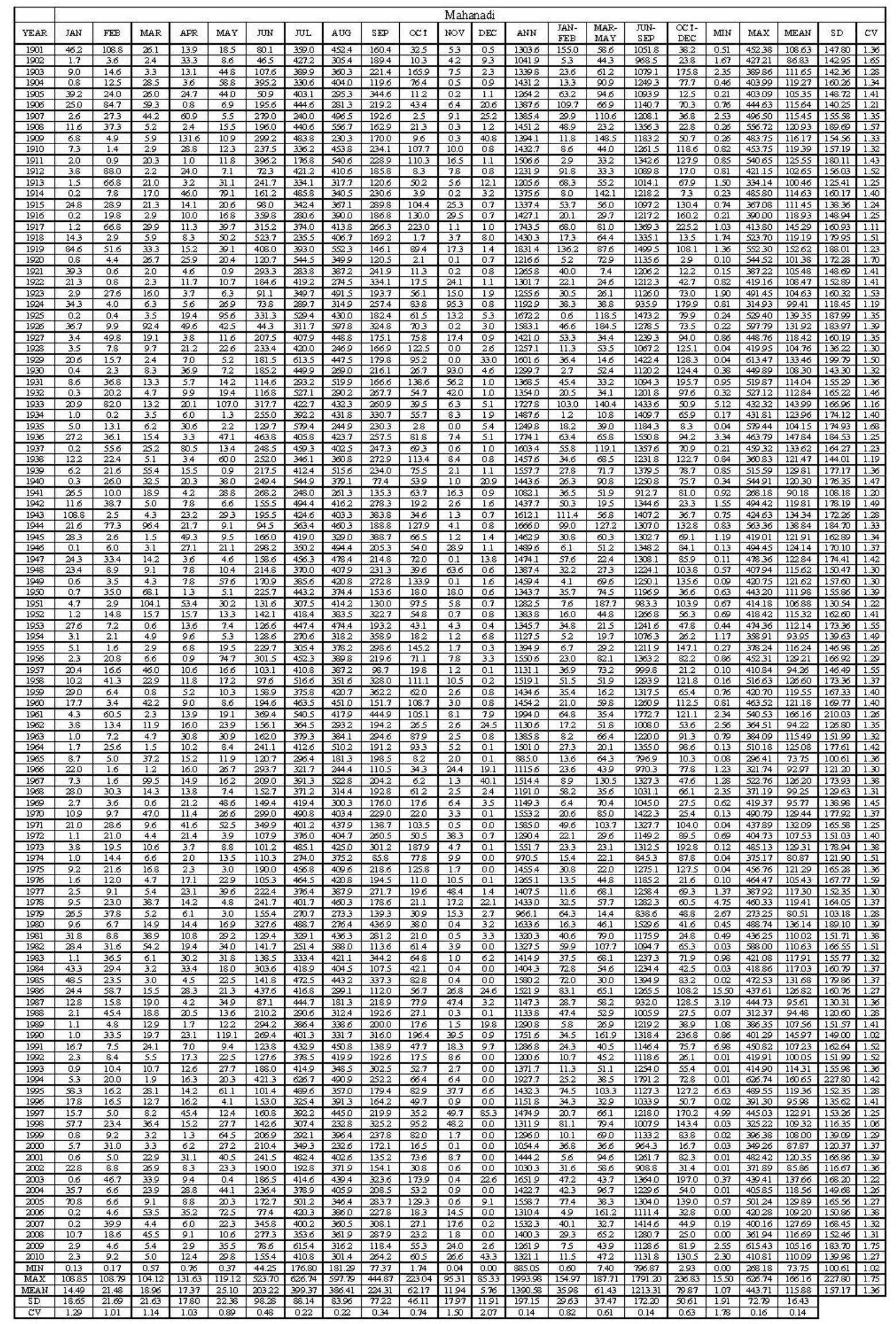


Characteristics of long-term variability of precipitation in selected river catchment areas in India ..

Table 19. A statement of total monthly precipitation $[\mathrm{mm}]$ and selected statistics for the long-term period 1901 2010 in the Godavari river area

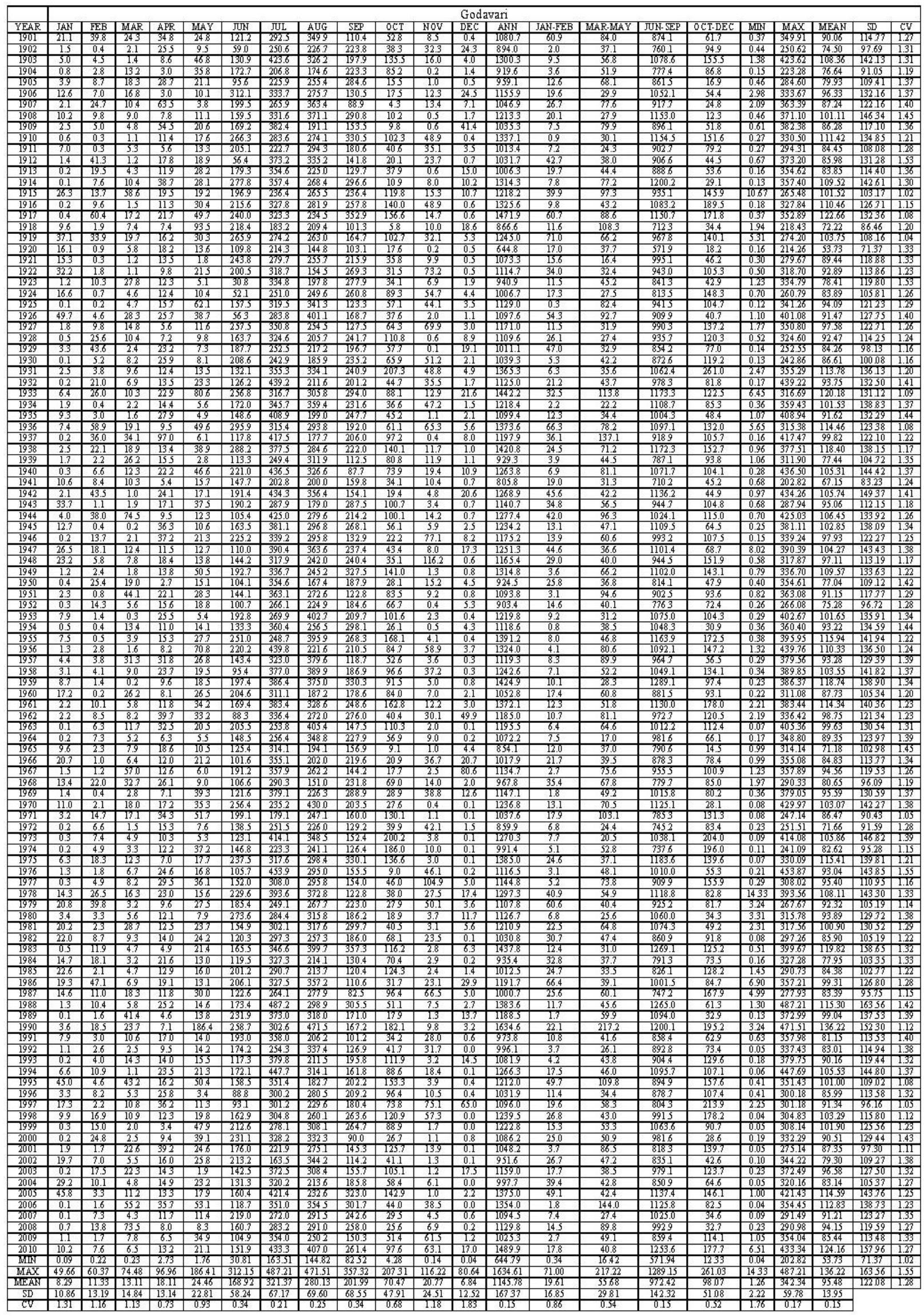


Characteristics of long-term variability of precipitation in selected river catchment areas in India ..

Table 20. A statement of periodicity values (inverses of predominating frequencies) for mean monthly precipitation sequences in the analysed long-term period 1901-2010 in the selected catchment areas in India

\begin{tabular}{|c|c|c|c|c|c|c|c|c|c|c|c|c|c|c|c|c|c|}
\hline \multirow{3}{*}{$\begin{array}{l}\text { Analysed } \\
\text { sequence profile }\end{array}$} & \multicolumn{12}{|c|}{ Months of the calendar year } & \multicolumn{5}{|c|}{ Statistics of } \\
\hline & 'T' & 'II' & 'III' & TV' & 'V' & 'VI' & 'VII' & 'VIII' & 'TX' & $\mathrm{X}^{\prime}$ & 'XI' & 'XII' & MIN & MAX & MEAN & SD & $\mathrm{CV}$ \\
\hline & \multicolumn{17}{|c|}{ [years] } \\
\hline BRAHMAPUTRA & 4.54 & 4.36 & 2.48 & 109.00 & 2.66 & 4.19 & 36.33 & 54.50 & 54.50 & 8.38 & 2.02 & 3.11 & 2.02 & 109.00 & 109.00 & 109.00 & 4.04 \\
\hline INDUS & 3.76 & 13.63 & 7.79 & 5.19 & 7.79 & 3.89 & 2.42 & 2.32 & 4.04 & 13.63 & 2.10 & 4.74 & 2.10 & 21.80 & 2.32 & 2.79 & 3.63 \\
\hline GANGES & 12.11 & 4.19 & 2.53 & 18.17 & 7.27 & 2.48 & 2.14 & 3.63 & 7.27 & 13.63 & 2.60 & 6.06 & 54.50 & 6.41 & 2.32 & 2.73 & 21.80 \\
\hline MAHI & 36.33 & 12.11 & 3.89 & 2.73 & 4.36 & 21.80 & 2.42 & 3.11 & 3.63 & 13.63 & 3.03 & 2.10 & 2.79 & 3.52 & 3.52 & 3.52 & 2.22 \\
\hline NARMA & 12.11 & 36.33 & 6.06 & 2.27 & 3.76 & 27.25 & 2.42 & 2.42 & 5.45 & 13.63 & 10.90 & 2.14 & 3.52 & 54.50 & 2.32 & 109.00 & 5.45 \\
\hline TAPTI & 21.80 & 12.11 & 2.10 & 2.48 & 4.74 & 2.66 & 2.42 & 4.74 & 6.41 & 13.63 & 9.91 & 18.17 & 3.52 & 54.50 & 15.57 & 54.50 & 21.80 \\
\hline DAMODAR & 2.22 & 2.02 & 6.81 & 3.11 & 7.27 & 2.48 & 54.50 & 27.25 & 2.14 & 13.63 & 2.02 & 54.50 & 4.19 & 54.50 & 54.50 & 3.03 & 3.03 \\
\hline BRAHMANI & 3.41 & 3.41 & 6.41 & 2.27 & 4.74 & 2.48 & 2.53 & 3.21 & 2.42 & 13.63 & 9.08 & 2.18 & 109.00 & 3.63 & 3.21 & 10.90 & 3.03 \\
\hline KRISHNA & 4.95 & 3.89 & 2.66 & 2.02 & 2.73 & 2.22 & 5.45 & 7.79 & 2.14 & 9.91 & 15.57 & 3.11 & 6.41 & 15.57 & 15.57 & 15.57 & 3.76 \\
\hline PENNER & 109.00 & 2.66 & 21.80 & 2.66 & 3.03 & 4.95 & 3.11 & 2.48 & 3.63 & 9.91 & 2.37 & 3.89 & 6.81 & 2.66 & 2.87 & 2.66 & 4.95 \\
\hline CAUVERY & 109.00 & 2.22 & 2.66 & 54.50 & 3.52 & 2.06 & 4.95 & 2.37 & 2.14 & 54.50 & 15.57 & 4.95 & 2.66 & 2.66 & 7.27 & 2.66 & 3.52 \\
\hline MAHANADI & 3.41 & 3.52 & 3.41 & 2.27 & \begin{tabular}{|l|}
4.74 \\
\end{tabular} & 4.74 & 2.53 & 2.95 & 2.32 & 2.14 & 54.50 & 2.73 & 4.54 & 2.95 & 10.90 & 3.41 & 2.95 \\
\hline GODAVARI & 2.27 & 2.06 & 2.66 & 2.53 & 7.27 & 2.66 & 3.11 & 2.14 & 6.41 & 13.63 & 2.37 & 3.76 & 3.89 & 2.73 & 2.14 & 2.66 & 3.76 \\
\hline
\end{tabular}

Table 21. Values of parameters of the linear trend in monthly precipitation in a calendar year in the analysed long-term period $1901-2010$ in the selected river catchment areas in India

\begin{tabular}{|c|c|c|c|c|c|c|c|c|c|c|c|c|c|c|c|c|c|c|}
\hline & & \multicolumn{12}{|c|}{ Months of the calendar year } & \multicolumn{5}{|c|}{ Statistics of } \\
\hline & Units & 'T' & 'II' & 'III' & IT $\mathrm{V}^{\prime}$ & $\mathrm{I} \mathrm{V}^{\mathrm{\prime}}$ & 'VI' & 'VI' & 'VII' & 'IX' & $\mathrm{X} \mathrm{X}^{\prime}$ & 'XI' & 'XII' & MIN & MAX & MEAN & SD & $\mathrm{CV}$ \\
\hline \multicolumn{19}{|c|}{ BRAHMAPUTRA } \\
\hline Slope value, $a$ & \multirow{3}{*}{$n /$ year] } & -0.057 & -0.083 & -0.075 & -0.221 & 0.166 & -0.229 & -0.234 & -0.800 & -0.120 & -0.140 & -0.075 & -0.021 & 0.001 & -1.242 & -0.157 & -0.279 & -0.001 \\
\hline Lower limit at a $95 \%$ confidence level & & -0.120 & -0.170 & -0.252 & -0.464 & -0.180 & -0.662 & -0.758 & -1.336 & -0.478 & -0.383 & \begin{tabular}{|l|l|}
-0.167 \\
\end{tabular} & -0.075 & -0.020 & -1.646 & -0.252 & -0.390 & -0.002 \\
\hline Upper limit at a $95 \%$ confidence lev el & & 0.006 & 0.004 & 0.102 & 0.021 & 0.512 & 0.205 & 0.290 & -0.264 & 0.238 & 0.104 & 0.017 & 0.033 & 0.023 & -0.837 & -0.063 & -0.168 & -0.001 \\
\hline \multicolumn{19}{|c|}{ INDUS } \\
\hline $\begin{array}{c}\text { Slope value } \\
a\end{array}$ & \multirow{3}{*}{ [mm/year] } & -0.030 & 0.058 & -0.029 & $|-0.010|$ & 0.013 & 0.086 & 0.084 & -0.036 & \begin{tabular}{|c|}
-0.015 \\
\end{tabular} & 0.031 & 0.027 & -0.018 & 0.011 & -0.019 & 0.013 & -0.015 & -0.001 \\
\hline Lower limit at a $95 \%$ confidence level & & -0.134 & -0.056 & -0.158 & -0.095 & -0.054 & -0. & -0. & -0.2 & -0.1 & -0.039 & \begin{tabular}{|l|l|}
-0.018 \\
\end{tabular} & -0.1 & -0.008 & -0.187 & -0.024 & -0.061 & -0.1 \\
\hline Upper limit at a $95 \%$ confidence lev el & & 0.074 & 0.171 & 0.099 & 0.075 & 0.080 & 0.1 & 0.268 & 0.146 & 0.142 & 0.102 & 0.072 & 0.063 & 0.031 & 0.150 & 0.051 & 0.030 & 0.000 \\
\hline \multicolumn{19}{|c|}{ GANGE } \\
\hline Slope value, $a$ & \multirow{3}{*}[\mathrm{mm}/\mathrm{year}]{} & -0.005 & -0.024 & -0.033 & -0.003 & 0.027 & -0.005 & -0.060 & -0.314 & 0.025 & 0.034 & 0.026 & 0.018 & 0.009 & 0.245 & 0.033 & 0.079 & 0.000 \\
\hline Lower limit at a 9 & & -0.087 & -0.118 & -0.107 & -0.067 & -0.067 & -0.329 & -0.407 & -0.597 & -0.306 & -0.177 & \begin{tabular}{|c|}
-0.092 \\
\end{tabular} & -0.077 & 0.024 & -0.462 & -0.097 & -0.155 & -0.001 \\
\hline Upper limit at a $95 \%$ confidence lev el & & 0.078 & 0.070 & 0.041 & 0.062 & 0.122 & 0.319 & 0.287 & -0.031 & 0.356 & 0.245 & 0.041 & 0.042 & 0.007 & -0.029 & 0.031 & -0.003 & 0.000 \\
\hline \multicolumn{19}{|c|}{ MAHI } \\
\hline Slop & \multirow{3}{*}{ m/year] } & 008 & 013 & 014 & 017 & 065 & -0.034 & 0.095 & 0.502 & 122 & 022 & .080 & 0.016 & 000 & -0.017 & 060 & 0.033 & -0.001 \\
\hline Lower limit at a & & -0.038 & -0.032 & -0.049 & -0.004 & -0.151 & -0.417 & -0.612 & -0.266 & -0.563 & \begin{tabular}{|c|}
-0.194 \\
\end{tabular} & -0.040 & -0.018 & -0.001 & -0.706 & -0.054 & -0.164 & -0.002 \\
\hline Upper limit at a & & 0.022 & 0.007 & 0.021 & 0.038 & 0.021 & 0.350 & 0.802 & 1.269 & 0.808 & 0.238 & 0.201 & 0.049 & 0.000 & 0.672 & 0.174 & 0.231 & 0.000 \\
\hline \multicolumn{19}{|c|}{ NARMADA } \\
\hline Slope v & \multirow{3}{*}[\mathrm{mm}/\text{year}]{} & -0.019 & -0.022 & -0.006 & -0.032 & -0.003 & 0.118 & 0.087 & 0.249 & 0.160 & 0.004 & -0.017 & 0.004 & .003 & 0.306 & 0.044 & 0.071 & 0.000 \\
\hline Lower limit at a 95 & & -0.115 & -0.103 & -0.080 & -0.067 & -0.084 & -0.296 & -0.528 & -0.337 & -0.450 & -0.223 & \begin{tabular}{|l|l|}
-0.178 \\
\end{tabular} & \begin{tabular}{|l|l|}
-0.092 \\
\end{tabular} & -0.003 & -0.197 & -0.056 & -0.075 & -0.001 \\
\hline Upper limit at a $95 \%$ confidence lev el & & \begin{tabular}{|l|l|}
0.077 \\
\end{tabular} & 0.059 & 0.067 & 0.003 & 0.078 & 0.533 & 0.701 & 0.836 & 0.771 & 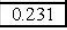 & \begin{tabular}{|l|l|l|l|l|l|l|l|l}
0.144 & \\
\end{tabular} & 0.100 & 0.008 & 0.810 & 0.144 & 0.218 & 0.001 \\
\hline \multicolumn{19}{|c|}{ TAPTI } \\
\hline Slope value & & -0.045 & -0.015 & 0.036 & 0.002 & 0.002 & 0.085 & 0.312 & 0.681 & 0.310 & 0.212 & 0.069 & -0.022 & 0.001 & 0.449 & 0.136 & 0.147 & -0.001 \\
\hline Lower limit at a $95 \%$ confidence level & m/year] & -0.112 & -0.065 & -0.023 & -0.029 & -0.092 & -0.2 & -0.099 & 0.227 & -0.178 & -0.059 & -0.141 & -0.098 & 02 & 0.106 & 0.054 & 0.037 & \\
\hline Upper limit at a $95 \%$ confidence lev el & & 0.022 & 0.034 & 0.095 & 0.033 & 0.097 & 0.433 & 0.724 & 1.136 & 0.799 & 0.483 & 0.279 & 0.054 & 0.004 & 0.793 & 0.218 & 0.256 & 0.000 \\
\hline & & & & & & & $\mathrm{OMC}$ & & & & & & & & & & & \\
\hline S & & -0.030 & -0.128 & -0.049 & -0.015 & 0.066 & -0.0 & 0.12 & -0.1 & 0.57 & 0.021 & 0.003 & 0.043 & 0.003 & 0.260 & 0.038 & 0.052 & 0.000 \\
\hline Lower lin & [mm/year] & \begin{tabular}{|l|l|}
-0.139 \\
\end{tabular} & -0.274 & -0.175 & -0.111 & -0.120 & -0.5 & -0.4 & -0.633 & 0.060 & -0.401 & \begin{tabular}{|l|l|}
-0.137 \\
\end{tabular} & \begin{tabular}{|l|l|}
-0.019 \\
\end{tabular} & -0.004 & -0.238 & -0.074 & -0.094 & -0.001 \\
\hline Upper limit at a $95 \%$ confidence lev el & & 0.079 & 0.018 & 0.077 & 0.082 & 0.251 & 0.5 & 0.71 & 0.351 & 1.090 & 0.443 & 0.144 & 0.105 & 0.010 & 0.758 & 0.151 & 0.199 & 0.001 \\
\hline & & & & & & & $\mathrm{RAH}$ & & & & & & & & & & & \\
\hline Slop & & \begin{tabular}{|c|}
-0.069 \\
\end{tabular} & 148 & -0.005 & -0.006 & 0.091 & -0.122 & -0.027 & -0.366 & 0.271 & 052 & 008 & .034 & 017 & 448 & 24 & 110 & 100 \\
\hline Lower limit at a & [mm/year] & -0.202 & -0.329 & -0.140 & -0.114 & -0.088 & -0.674 & \begin{tabular}{|l|l|}
-0.631 \\
\end{tabular} & -0.913 & -0.1 & -0.303 & \begin{tabular}{|l|l|l|l|l|}
-0.132 \\
\end{tabular} & $-0,037$ & 0.003 & -0.994 & -0.123 & -0.256 & -0.001 \\
\hline Upper limit at a & & \begin{tabular}{|l|l|}
0.063 \\
\end{tabular} & 0.032 & 0.130 & 0.102 & 0.270 & 0.430 & 0.578 & 0.181 & 0.712 & 0.407 & \begin{tabular}{|l|l|}
0.149 \\
\end{tabular} & 0.105 & 0.032 & 0.098 & 0.075 & 0.036 & 0.000 \\
\hline & & & & & & & RISHN & & & & & & & & & & & \\
\hline $\mathrm{Sl}$ & & -0.016 & -0.022 & 0.062 & 0.024 & 0.121 & 0.104 & 0.039 & 0.308 & $\overline{66}$ & 241 & 039 & -0.038 & 001 & 173 & 65 & 0.069 & 0.000 \\
\hline Lower limit at a 9 & [mm/year] & -0.048 & -0.057 & -0.008 & -0.052 & -0.035 & -0.089 & -0.255 & 0.023 & \begin{tabular}{|c|}
-0.342 \\
\end{tabular} & -0.058 & \begin{tabular}{|l|}
-0.231 \\
\end{tabular} & -0.106 & -0.005 & -0.070 & 0.003 & -0.004 & -0.001 \\
\hline \begin{tabular}{|l} 
Upper limit at a 9 \\
\end{tabular} & & \begin{tabular}{|l|l|}
0.017 \\
\end{tabular} & \begin{tabular}{|l|l|}
0.014 \\
\end{tabular} & 0.133 & 0.101 & 0.277 & 0.29 & 0.33 & 0.5 & 0.33 & \begin{tabular}{|l|l|}
0.540 \\
\end{tabular} & \begin{tabular}{|l|l|}
0.154 \\
\end{tabular} & 0.029 & 0.003 & 0.416 & 0.126 & 0.143 & 0.001 \\
\hline & & & & & & & EENNER & & & & & & & & & & & \\
\hline Slo & & -0.095 & -0.027 & 0.048 & 0.069 & 0.205 & 0.157 & 0.05 & 0. & -0.209 & 0. & -0.200 & -0.0 & -0.005 & 0.1 & 45 & 0.052 & 0.000 \\
\hline Lower lir & [mm/year] & -0.166 & -0.080 & -0.029 & -0.034 & -0.013 & -0.043 & -0.206 & -0.129 & -0.551 & -0.090 & \begin{tabular}{|l|}
-0.533 \\
\end{tabular} & -0.151 & -0.010 & -0.116 & -0.025 & -0.035 & -0.001 \\
\hline Upper limit at a 95\% con & & -0.023 & 0.025 & \begin{tabular}{|l|l|}
0.124 \\
\end{tabular} & 0.172 & 0.424 & 0.356 & 0.317 & 0.597 & 0.133 & 0.700 & \begin{tabular}{|l|l|}
0.133 \\
\end{tabular} & \begin{tabular}{|l|l|}
0.149 \\
\end{tabular} & 0.000 & 0.490 & 0.115 & 0.139 & 0.001 \\
\hline & & & & & & & AUT & & & & & & & & & & & \\
\hline Slope value & & -0.116 & $\mid-0.016$ & 0.084 & 0.149 & -0.082 & -0.095 & $-0.290 \mid$ & $-0.087 \mid$ & 0.018 & 0.190 & 0.067 & 0.013 & -0.005 & 0.056 & -0.014 & -0.004 & 0.000 \\
\hline Lower lim & {$[\mathrm{mm} / \mathrm{year}]$} & 0.196 & 0.084 & 0.027 & -0.02 & 0.335 & 0.2 & -0.571 & -0.36 & -0.2 & -0.2 & \begin{tabular}{|l|}
-0.272 \\
\end{tabular} & -0.173 & -0.019 & -0.242 & & -0.076 & -0. \\
\hline Upper limit at a $95 \%$ confidence lev el & & -0.035 & 0.052 & 0.196 & 0.320 & 0.171 & 0.106 & -0.009 & 0.188 & 0.303 & \begin{tabular}{|c|c|c|}
0.593 \\
\end{tabular} & 0.406 & 0.198 & 0.008 & 0.354 & 0.053 & 0.069 & 0.001 \\
\hline & & & & & & & $\mathrm{AHA}$ & & & & & & & & & & & \\
\hline Slope value & & 0.006 & -0.132 & -0.004 & -0.078 & 0.030 & -0.206 & 0.163 & -0.331 & 0.153 & -0.006 & 0.010 & 0.026 & 0.006 & -0.352 & -0.031 & -0.069 & 0.000 \\
\hline Lower & {$[\mathrm{mm}$} & -0.105 & -0.255 & -0.133 & 0.18 & -0.103 & -0.7 & -0.36 & -0.8 & -0.30 & -0.282 & -0.097 & -0.045 & -0.005 & -0.782 & & -0.193 & -0.001 \\
\hline Upper limit at a $95 \%$ confidence lev el & & \begin{tabular}{|l|l|l|l|l|l|}
0.118 \\
\end{tabular} & -0.005 & 0.125 & 0.027 & 0.164 & 0.380 & 0.690 & 0.167 & 0.614 & 0.269 & \begin{tabular}{|l|l|l|l|l|l|}
0.118 \\
\end{tabular} & 0.098 & 0.018 & 0.078 & 0.067 & 0.055 & 0.000 \\
\hline & & & & & & & $\mathrm{ODA}$ & & & & & & & & & & & \\
\hline Slop: & & 0.017 & -0.056 & 0.046 & -0.049 & 0.028 & -0.1 & 0.225 & 0.345 & -0.1 & 0.211 & \begin{tabular}{|c|}
0.003 \\
\end{tabular} & -0.008 & 0.000 & 0.270 & 0.045 & 0.053 & 0.000 \\
\hline fidence level & [mm/year] & -0.048 & -0.134 & -0.042 & -0.127 & -0.109 & -0.4 & -0.175 & -0.066 & -0.526 & -0.072 & -0.143 & -0.082 & -0.014 & -0.084 & -0.038 & -0.052 & -0.001 \\
\hline Upper limit at a $95 \%$ confidence lev el & & 0.081 & 0.022 & 0.135 & 0.029 & 0.164 & 0.241 & 0.624 & 0.756 & 0.293 & 0.495 & 0.150 & 0.067 & 0.013 & 0.623 & 0.128 & 0.158 & 0.001 \\
\hline
\end{tabular}

\section{Conclusion}

The strategic plans and ambitious objectives included in the water management programme for India are regrettably accompanied by numerous contrasts between extremely dramatic growth projects and poor knowledge of local environmental conditions and by attempts to import Western, supposedly universal models that ignore local and regional features and characteristics of the territory. The Ministries of Water Resources and of Agriculture and the Planning Commission are responsible for water management on a national scale; additionally, the government is authorised by the Constitution to manage river drainage basins. These statutory and organizational instruments provide great opportunities for implementation of the adopted water mission, but 
further excessive exploitation of water resources with a continued low efficiency of water intake use may cause a durable and dramatic reduction in available water resources and impair their quality. The study contains an analysis of precipitation, covering multiple profiles and based on the GPCC database that provides monthly mean values for the territory of India, in 13 river catchment areas. Brahmaputra, Indus, Ganga, Mahi, Narmada, Tapti, Damodar, Brahmani, Krishna, Penner, Cauvery, Mahanadi and Godavari. The catchment areas and their closing cross-sections are defined using data made available by the GRDC agency (Table 1). The analysis includes data for the period 1901-2010 with a spatial resolution of $0.5^{\circ} \mathrm{x}^{\circ} 0.5^{\circ}$ of geographic longitude and latitude. The data is analysed in calendar year profiles. The periodical nature of precipitation is assessed and the trends in climate changes calculated. The characteristics of trend in climate changes are described by linear equations with indicated boundary values of coefficients determined at a 5\% significance level.

The long-term mean annual total of precipitation in the territory of India is estimated at $1126 \mathrm{~mm}$ and the mean values in the analysed period of 110 years vary from $894 \mathrm{~mm}$ to $1387 \mathrm{~mm}$. The standard deviation of mean value of annual total precipitation reaches $10 \%$ and the coefficient of variation amounts to 0.08 . The sum of mean precipitation volume in the long-term period amounts to $3704 \mathrm{~km}^{3}$, showing a positive trend of 68 [million $\mathrm{m}^{3} /$ year]. The trend in the mean value of precipitation in the territory of India is positive: 0.021 [mm/year].

The periodicity of precipitation in all analysed river catchment areas is characterised by minimum values of predominating repeatability periods of about 2 years while maximum values vary from 13 to 15 years in the catchment areas of Indus, Ganga, Brahmani and Krishna, amount to 22 years in the Tapti catchment area, 36 years in the Mahi and Narmada catchment areas, 55 years in the Damodar catchment area; with no indications for the Brahmaputra, Penner and Couvery rivers. The maximum value of linear precipitation trend in the analysed catchment areas is observed in the Tapti river: 0.681 [mm/year], and the lowest, negative value - in the Brahmaputra river: -0.803 [mm/year]. The trend in mean values for the analysed long-term period varies from -0.159 [mm/year] for the Brahmaputra to 0.136 [mm/year] for the Tapti river. Positive trends in mean precipitation values are observed in the Indus, Mahi, Narmada, Tapti, Damodar, Krishna, Penner and Godavari river catchment areas, negative trends in precipitation values are identified in the Brahmaputra, Ganga, Brahmani, Cauvery and Mahanadi river catchment areas.

The analyses discussed confirm spatial and temporal variability of precipitation in the key river catchment areas in India, feeding the country's surface and underground water resources. The statistics contained in this study demonstrate the regional nature of water supply, indicate the need to complete regional analyses of temporal and spatial variations in the volumes of water feeding Indian resources, and confirm that regional and local plans must be developed to adapt to climate change, based on the accepted scenarios aimed to compensate climate change effects.

\section{References}

[1]. A. Becker, P. Finger, A. Meyer-Christoffer, B. Rudolf, K. Schamm, U. Schneider, and M. Ziese, A description of the global landsurface precipitation data products of the Global Precipitation Climatology Centre with sample applications including centennial (trend) analysis from 1901-present, Global Precipitation Climatology Centre, Deutscher Wetterdienst, Offenbach, Germany, 2013

[2]. Adler, R.F., G.J. Huffman, A. Chang, R. Ferraro, P. Xie, J. Janowiak, B. Rudolf, U. Schneider, S. Curtis, D. Bolvin, A. Gruber, J. Susskind, P. Arkin and E. Nelkin (2003): The Version-2 Global Precipitation Climatology Project (GPCP) Monthly Precipitation analysis (1979- present). J. Hydrometeorol., 4, 1147-1167.

[3]. All India Area Weighted Monthly, Seasonal and Annual Rainfall in Mm 1901- 2010 from the Revised Series Computed Using all Available Raingauge Stations Data and From IMD District Rainfall Data Series while The Period 2011-2014 Are Based On The Realtime Drms Data, India Meteorological Department, Ministry of Earth Sciences, Climate Application Group, https://data.gov.in/catalog/all-india-area-weighted-monthly-seasonal-and-annual-rainfall-mm, http://www.imdpune.gov.in/hydrology/

[4]. Ashwini A. Ranade, Nityanand Singh, H.N. Singh and N.A. Sontakke, Characteristics of Hydrological Wet Season over Different River Basins of India, , Indian Institute of Tropical Meteorology, , September 2007

[5]. Ashwini Ranade, Nityanand Singh, H.N. Singh and N.A. Sontakke, On Variability Of Hydrological Wet, Season, Seasonal Rainfall And Rainwater Potential Of The River Basins Of India (1813-2006), Indian Institute Of Tropical Meteorology, Journal Of Hydrological Research And Development, Vol. 23, 2008

[6]. P. Guhathakurta , P. A. Menon, S. K. Dikshit and S. T. Sable, Extreme Rainfall Analysis Of Andhra Pradesh Using A Probability Distribution Model : A Regional Estimate, MAUSAM, 56,4,2005, 785-794.

[7]. P. Guhathakurta and E. Saji, Detecting changes in rainfall pattern and seasonality index vis-à-vis increasing water scarcity in Maharashtra, J Earth Syst. Sci. 122, 3, 2013, 639-649, ,

[8]. P. Guhathakurta and M. Rajeevan, Trends in rainfall pattern over India, International J. of Climatology, 28: $1453-1469$, 2008.

[9]. P. Guhathakurta, A. Tyagi and B. Mukhopadhyay, Climatology at any point : A neural network solution, Mausam, 642, 2013, 231250 .

[10]. P. Guhathakurta, Drought in districts of India during the recent all India normal monsoon years and its probability of occurrence, MAUSAM, 54, 2, 2003, 542-545.

[11]. P. Guhathakurta, Highest recorded point rainfall over India, Weather, December 2007, Vol. 62, No. 12

[12]. P. Guhathakurta, O P Sreejith and P. A. Menon, Impact of climate changes on extreme rainfall events and flood risk in India, J. Earth System Science. 120, No. 3, 359-373,

[13]. P. Guhathakurta, Rainfall network of India and the recent rainfall normals, Indian J of Power and River Valley development, 56, $11 \& 12,2006,254-259$. 
[14]. Rakesh Kumar, R. D. Singh and K. D. Sharma, Water resources of India, National Institute of Hydrology, Roorkee 247 667, India, Current Science, vol. 89, no. 5, 10 September 2005

[15]. Rudolf, B., and U. Schneider (2005), Calculation of gridded precipitation data for the global land-surface using in-situ gauge observations. Proceedings of the 2nd Workshop of the International Precipitation Working Group IPWG, Monterey, October 2004, 231-247.

[16]. Twaróg B., Zmiana charakterystyki opadów atmosferycznych w ostatnich latach i jej wpływ na wymiarowanie urządzeń odwadniających. Dostępność i jakość danych do projektowania pozyskiwanych z IMIGW, II Ogólnopolskie Forum Specjalistyczne „Odwodnienie dróg, kolei i mostów w aspektach bezpieczeństwa ruchu i ochrony środowiska, Odwodnienie 2014, Kraków, 4 - 5 czerwca 2014 r.

[17]. Twaróg B., Characteristics of long-term variability of precipitation in the territory of Poland based on GPCC data for the years 1901, IOSR Journal of Environmental Science, Toxicology and Food Technology (IOSR-JESTFT) e-ISSN: 2319-2402,p- ISSN: 2319-2399. Volume 10, Issue 10 Ver. I (Oct. 2016), PP 50-64, 2016

[18]. U. Schneider, M. Ziese, A. Becker, A. Meyer-Christoffer, P. Finger, Global Precipitation Analysis Products of the GPCC, Global Precipitation Climatology Centre (GPCC) Deutscher Wetterdienst, Offenbach a. M., Germany, May 2015 